\title{
Improvement in the Pharmacological Profile of Copper Biological Active Complexes by Their Incorporation into Organic or Inorganic Matrix
}

\author{
Mihaela Badea ${ }^{1}\left(\mathbb{D}\right.$, Valentina Uivarosi ${ }^{2, *(\mathbb{D})}$ and Rodica Olar ${ }^{1, *(\mathbb{D})}$ \\ 1 Department of Inorganic Chemistry, Faculty of Chemistry, University of Bucharest, 90-92 Panduri Str., \\ 050663 Bucharest, Romania; mihaela.badea@chimie.unibuc.ro \\ 2 Department of General and Inorganic Chemistry, Faculty of Pharmacy, Carol Davila University of Medicine \\ and Pharmacy, 6 Traian Vuia Str., 020956 Bucharest, Romania \\ * Correspondence: valentina.uivarosi@umfcd.ro (V.U.); rodica.olar@chimie.unibuc.ro (R.O.)
}

Academic Editor: Mauro Ravera

Received: 15 November 2020; Accepted: 7 December 2020; Published: 10 December 2020

\begin{abstract}
Every year, more $\mathrm{Cu}$ (II) complexes are proven to be biologically active species, but very few are developed as drugs or entered in clinical trials. This is due to their poor water solubility and lipophilicity, low stability as well as in vivo inactivation. The possibility to improve their pharmacological and/or oral administration profile by incorporation into inorganic or organic matrix was studied. Most of them are either physically encapsulated or conjugated to the matrix via a moiety able to coordinate $\mathrm{Cu}(\mathrm{II})$. As a result, a large variety of species were developed as delivery carriers. The organic carriers include liposomes, synthetic or natural polymers or dendrimers, while the inorganic ones are based on carbon nanotubes, hydrotalcite and silica. Some hybrid organic-inorganic materials based on alginate-carbonate, gold-PEG and magnetic mesoporous silica-Schiff base were also developed for this purpose.
\end{abstract}

Keywords: complex; copper(II); matrix; formulation; antimicrobial activity; biofilm

\section{Introduction}

Nowadays, the aspects concerning the use of metallodrugs as an alternative for organic molecules is an important aspect of modern medicine, and some of the metal complexes that are rapidly gaining credit in this field are those of copper. The use of copper for this purpose can be traced to ancient Egypt, where this metal was used for water sterilization, while its compounds were used for wounds disinfection in the chest area. Additionally, a mixture of copper oxide and honey/rose oil was used in antiquity for wound disinfection and deworming. The powder malachite (copper hydroxide carbonate, $\left.\mathrm{Cu}_{2} \mathrm{CO}_{3}(\mathrm{OH})_{2}\right)$ and copper oxide were used for ophthalmic conditions in ancient Persia [1].

The effect of copper on the immune system was first mentioned in 1867, during the cholera epidemics of that period in France, when it was noted that people working in copper mines did not get sick. Later, in 1939, the therapeutic potential of copper in the treatment of rheumatic diseases was discovered when it was observed that Finnish miners from copper exploitations did not suffer from rheumatism [1].

Nowadays there are some copper compounds used as drugs or supplements either to manage the neurological disorders in Menkes disease or for the treatment of some conditions based on its ability to coordinate and interact with a wide range of biomolecules. Among them, copper acetate $\left[\mathrm{Cu}_{2}\left(\mathrm{CH}_{3} \mathrm{COO}\right)_{4}\left(\mathrm{OH}_{2}\right)_{2}\right](\mathbf{1})$ and histidinate $\left[\mathrm{Cu}(\mathrm{His})_{2}\right](2)$ (HHis is histidine) are used in the intravenous (i.v.) administration for relieving symptoms in Menkes disease [2] (Figure 1). Copper sulphate and gluconate $\left[\mathrm{Cu}(\mathrm{glu})_{2}\right](3)$ (HGlu is gluconic acid) are usually found in the complex medication of 
iron-deficiency anemia [3,4], while chlorophyllin (4) in pills, spray or ointment formulations is recommended for wound odor elimination, radiation burns, inflammatory diseases and even for liver cancer prevention [5-7]. The mammalian $\mathrm{Cu}, \mathrm{Zn}$-superoxide dismutase (SOD1 oxidized active site (5)) formulated as injection or cream is recommended for inflammatory diseases. This enzyme is also recommended in diabetic complications, atherosclerosis, Alzheimer's disease, cancer as well as in rheumatic arthritis [8-12]. Some ointments containing $\mathrm{Cu}(\mathrm{II})$ and $\mathrm{Zn}(\mathrm{II})$ glycinates, such as [Cu(Gly)] (HGly is glycine) (6), are recommended for skin conditions [13].

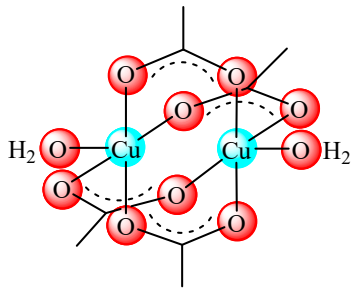

(1)

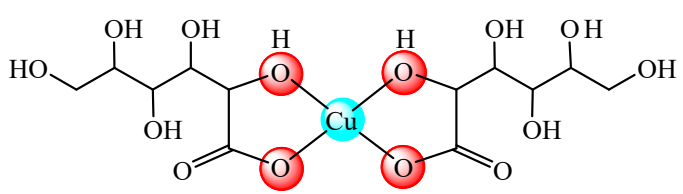

(3)

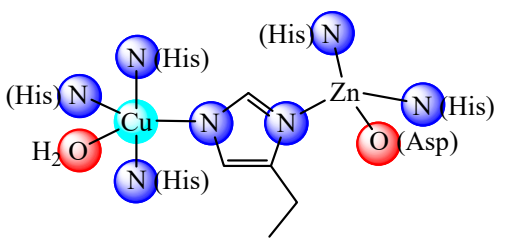

(5)

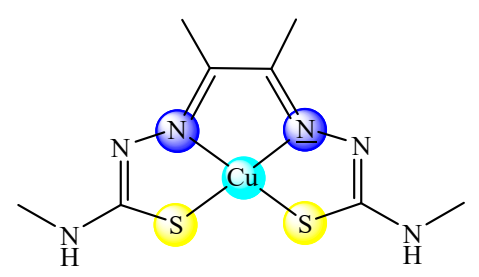

(7)<smiles>O=C1C=C(Cc2cnc[nH]2)C(=O)O1</smiles>

(2)

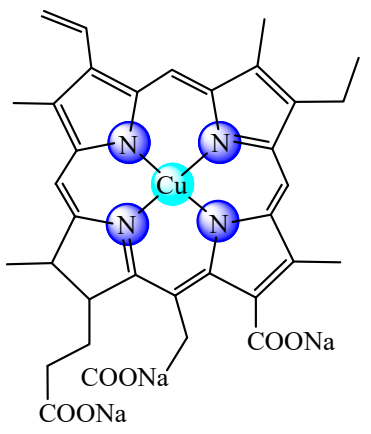

(4)

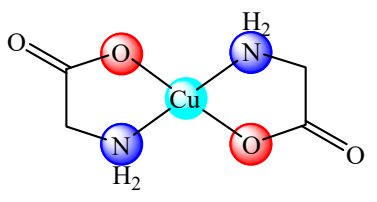

(6)

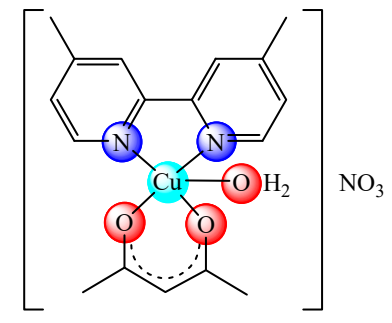

(8)

Figure 1. Copper-based drugs: $\left[\mathrm{Cu}_{2}\left(\mathrm{CH}_{3} \mathrm{COO}\right)_{4}\left(\mathrm{OH}_{2}\right)_{2}\right](\mathbf{1})$ and $\left[\mathrm{Cu}(\mathrm{His})_{2}\right](2)$ for relieving symptoms in Menkes disease, $\left[\mathrm{Cu}(\mathrm{glu})_{2}\right]$ (3) for iron deficiency anemia, chlorophyllin (4) for wounds odors elimination, radiation burns, inflammatory diseases and liver cancer prevention, SOD1 (5) for inflammatory diseases, diabetic complications, atherosclerosis, Alzheimer's disease, cancer and rheumatic arthritis, [Cu(Gly)] (6) for skin conditions, $[\mathrm{Cu}(\mathrm{atsm})](7)$ for amyotrophic lateral sclerosis and $\left[\mathrm{Cu}(\mathrm{dmbpy})(\mathrm{acac})\left(\mathrm{OH}_{2}\right)\right] \mathrm{NO}_{3}$ (8) for cancer.

Moreover, $\left[\mathrm{Cu}(\right.$ atsm) $]$ (7) $\left(\mathrm{H}_{2}\right.$ atsm is diacetylbis(N-4-methylthiosemicarbazone) as a drug for amyotrophic lateral sclerosis (ALS) [14], $\left[\mathrm{Cu}(\mathrm{dmbpy})(\mathrm{acac})\left(\mathrm{OH}_{2}\right)\right] \mathrm{NO}_{3}$ (dmbpy is 
4,4-dimethyl-2,2' -bipyridine, Hacac is acetylacetone) (8) from the Casíopeinas ${ }^{\circledR}$ family [15] as well as (4) combined with disulfiram (dsf) [16] as antitumor drugs are currently underway in clinical trials.

Copper was selected for medical purposes because of: (i) its essential character, (ii) the borderline behavior as a Lewis acid, (iii) the stereochemical versatility, (iv) the ability to change its oxidation state and (v) the relative low systemic toxicity. This is an essential element found in traces in the human body at a level of $0.11 \mathrm{~g} / 70 \mathrm{~kg}$. As component of copper-proteins, it plays an important role in many redox processes as a result of easy oxidation state changing between +1 and +2 . Among them, the copper-enzymes are involved in iron homeostasis, superoxide disproportionation, melanin, catecholamines and neuropeptide synthesis as well as collagen with elastin cross-linking [17-20].

In the human body, $\mathrm{Cu}(\mathrm{II})$ can interact with a wide range of biomolecules as a result of its ability to coordinate both hard and soft ligands. The interaction with DNA and proteins is exploited in order to develop some valuable antitumor, anti-inflammatory and antimicrobial species [17-20]. On the other hand, the interaction with cytosolic peptides glutathione and metallothioneins can inactivate the $\mathrm{Cu}$ (II) complexes [21]. The Jahn Teller effect that operate for $\mathrm{Cu}$ (II) complexes together with ligand properties are responsible for the wide range of known stereochemistries for this ion. The ability to easily change the stereochemistry explains the interaction with different biomolecules, an interaction that can also be assisted by the ligand [17-20].

Due to its redox properties, copper is involved both in the regulation of physiological processes and in the generation of highly reactive oxygen species (ROS), both responsible for its antitumor activity. The $\mathrm{Cu}$ (II) complexes with an appropriate potential are reduced by superoxide anion to $\mathrm{Cu}(\mathrm{I})$ species that reduce $\mathrm{H}_{2} \mathrm{O}_{2}$ resulted by SOD1 activity to $\mathrm{HO}$, radical responsive by DNA strands splitting [22].

The copper homeostasis is well-tuned, and as a result, any copper excess is stored as a complex with metallothioneins [17-20,23]. This metal ion capture provides a way to reduce the complexes' toxicity. However, the copper toxicity is manifested in Wilson disease, where the organism escapes the normal metabolic pathways and allows the metal accumulation in the liver [17]. Wilson's disease is manifested by neurological and liver damages and the appearance of a characteristic brown ring in the periphery of the cornea ("Kayser-Fleischer ring"), accompanied by increased copper levels in urine and the affected brain [24]. The non-Wilson's disease disorders (copper toxicosis), such as Indian childhood cirrhosis (ICC), Idiopathic copper toxicosis and endemic Tyrolean infantile cirrhosis, appear to be caused by excessive accumulation of copper uptake through food and drinking water, although a genetic predisposition has also been linked to ICC-like illness [25]. Excessive copper intake can cause a metallic taste, salivation nausea, vomiting, abdominal pain and cramps, headache, dizziness, weakness and diarrhea. High uptakes of copper may cause liver and kidney damage, neurodegenerative disorders and even death [26]. Toxic concentrations of copper can occur when copper ingestion is over $1 \mathrm{~g}$ (usually taken in suicide attempts) and the estimated lethal dose in an untreated adult is 10-20 g. Systemic toxicity occurs at serum copper levels of $78.5 \mu \mathrm{mol} / \mathrm{L}$ [27]. The human body makes contact with a large variety of sources of cooper, including copper water pipes, copper cookware, drinking water, foods, birth control pills and $\mathrm{Cu}$ intrauterine devices, vitamin and minerals supplements, fungicides and added copper in swimming pools $[25,28]$. These concerns regarding copper toxicity must be taken into account for biologically active copper complexes.

Many copper complexes were designed as versatile and reliable tools for developing biologically active compounds. The ligand structure and ability to both enhance the stability and regulate the non-covalent interactions with biomolecules were selected in order to finely tune the complexes' desirable properties [29]. As a result, many copper complexes with potential therapeutic activities were developed. The biological application of these complexes extends from enzyme inhibition or species with enzyme-like activity [30-33] to active species with antimicrobial, anti-inflammatory or antitumor activity [17-20,22,23,29,34-41], aspects presented in several reviews.

However, a small number of copper-based drugs are in current use as a result of reduced stability both in water and acidic environment and an unfavorable balance between water solubility and lipophilicity. In order to solve these problems, some delivery carriers have been developed 
to increase both the drug protection and efficacy. These systems were developed based on the data obtained during the attempts to improve the similar issues related to platinum-based drugs. As a result, the copper systems were combined with a wide range of organic, inorganic or hybrid (organic-inorganic)-based carriers.

\section{Delivery Systems for Copper Active Complexes}

\subsection{Organic-Based Carriers}

Biologically active copper complexes (bacc) administrated through a delivery system are protected against rapid metabolism in the presence of hydrochloric acid, water or serum and cytoplasmic proteins before the interaction with the target biomolecules. Moreover, such systems enhance the half-life of active compound in the blood stream and increase its cellular uptake by endocytosis, especially in tumor tissues, which are characterized by an Enhanced Permeability and Retention effect (EPR effect) [42].

Based on the experience achieved in platinum-based drugs encapsulation, several bacc were either physically encapsulated into a functionalized organic or inorganic matrix or conjugated to its backbone via a multichelate coordinative site. The matrix can be a synthetic one, selected from what is usually tested as biocompatible and biodegradable and already used in pharmaceutical formulations, or can be a natural polysaccharide or protein system.

Physical encapsulation is rarely explored for $\mathrm{Cu}$ (II) complexes, since it depends on the both the solubility and polarity of the compound. Only a few delivery systems, where the bacc is not conjugated to a matrix, have been reported so far. Besides polymeric systems, bacc encapsulation into liposomes also seems to be a good strategy in the field. The reported data indicate that the polymer-drug conjugation is by far the preferred approach, since the chelate coordination enhances the stability, and as a result, the circulating time of active compounds in the body [43]. For such systems, the type of polymer, its functionalization as well as properties and structure of complexes are extremely important factors in order to achieve the desired properties.

\subsubsection{Liposomal Systems}

Liposomes are spherical vesicles with an aqueous core surrounded by a lipid bilayer similar in morphology as natural phospholipid membranes. As a result, these systems are suitable to encapsulate both hydrophilic species in the aqueous core and hydrophobic ones into the lipid bilayer [44].

Based on the experience gained in encapsulation of other inorganic species, some liposomal formulations were developed for bacc, in order to improve their water solubility and deliverability rate as presented in Table 1. Thus, dimyristoyl phosphatidylcholine (DMPC)-based long circulating nanoliposomes containing $\left[\mathrm{Cu}\right.$ (phen) $\left.\mathrm{Cl}_{2}\right]$ (phen is 1,10-phenantroline) (9), a potent aquaporin inhibitor, were developed and assayed against several melanoma and colon cancer cells. All cell lines were sensitive with a half-inhibitory concentration $\left(\mathrm{IC}_{50}\right)$ value around $3 \mu \mathrm{M}$. Furthermore, the in vivo studies revealed no toxic effects after parenteral administration [45]. The same complex in another nanoliposomal formulation demonstrated high antitumor efficacy and safety in order to develop more effective therapeutic strategies against melanoma. In vivo data demonstrated that DMPC-based Cuphen nanoliposomes significantly impaired melanoma progression with no toxic side effects [46].

A series of complexes of type $\left[\mathrm{Cu}(\mathrm{inh})_{2} \mathrm{X}_{2}\right] \cdot \mathrm{nH}_{2} \mathrm{O}$ (inh is isoniazid; $\mathrm{X}$ is $\mathrm{Cl}(10), \mathrm{NCS}$ (11) and $\mathrm{NCO}(12)$ ) were incorporated in a nanostructured lipid system and exhibited an enhanced in vitro anti-Mycobacterium tuberculosis (Mtb) activity [47]. The same systems were considerably more selective than the unloaded compounds in interaction with Escherichia coli and Staphylococcus aureus strains; in some cases, the activity was up to 40 times higher [48].

The complex [Cu(ddc) 2 (Hddc is diethyldithiocarbamic acid) (13) was tested, and proved more active than Hddc on glioblastoma (U251MG), human non-small cell lung cancer (A549) and breast cancer (MDA231-BR) cell lines. As a result, the compound was in situ synthesized into lipid vesicles and was developed as an injectable product for antitumor 
purposes [49]. The species $\left[\mathrm{CuCl}_{2}\right]_{\mathrm{n}}$ and $\left[\mathrm{Cu}\left(\mathrm{OH}_{2}\right)_{4}\right] \mathrm{SO}_{4} \cdot \mathrm{H}_{2} \mathrm{O}$ were embedded into stealth liposomes composed of 1,2-dipalmitoyl-sn-glycero-3-phosphatidylcholine (DPPC):cholesterol (CHOL):dipalmitoylphosphoethanolamine-N-[methoxy(polyethyleneglycol)-2000] ammonium salt (DPPE-PEG2000) and tested on human prostate cancer cell line (PC-3) both in vitro and in vivo. These formulations injected into tumor-bearing mice were effective in reducing the overall tumor burden [50]. Thermosensitive PEGylated liposomes based on DPPC and hydrogenated soybean phosphatidylcholine (HSPC) were used in order to incorporate the $\left[\mathrm{Cu}(\mathrm{ncr})_{2}\right] \mathrm{SO}_{4}$ (ncr is neocuproine or 2,9-dimethyl-1,10-phenanthroline) complex (14). These systems were effective in reducing the tumor growth of mouse colon carcinoma cells (C26) grafted in mice [51].

A liposomal formulation based on DSPC:CHOL containing a copper quercetin complex (15) with enhanced circulation longevity was recently developed and studied as system suitable for parenteral use in cancer treatment [52]. The vesicular assembly of metallosomes type developed by CHOL incorporation into cetylpyridinium chloride (CPC) surfactant in $\mathrm{Cu}(\mathrm{II})$ presence exhibits the ability to inhibit methicillin-resistant S. aureus (MRSA) strain [53].

The post-burn inflammation processes associated with thermally injured tissue gives rise to ROS overproduction. As a result, the influence of SOD1, free or liposomal encapsulated, on thermally injured tissue of rabbit skin was examined and the best result was achieved by spreading the liposomal formulation over the wounds. The liposomal formulation consisted in DPPC:CHOL/SA (stearylamine) in a molar ratio of 7:2:1 [54].

The therapeutic potential of some SOD1-containing polyethylene glycol (PEG)-liposomes was studied and compared with that of SOD1 entrapped in (SA)-liposomes and free SOD1 administered by (i.v.) injection in an arthritic rat model. Both small PEG-liposomes and SA-liposomes exhibited an enhanced therapeutic potential in comparison with SOD1, the PEG-liposomes being the most potent [55]. This enzyme was also covalently attached to the distal terminus of PEG polymer chains functionalized with maleimide, and this system was loaded at the surface of lipid vesicles composed of PC:CHOL in order to obtain SOD1-enzymosomes. The in vivo assays showed that SOD1-enzymosomes showed therapeutic activity in rat adjuvant arthritis both compared to liposomes with SOD1 encapsulated in their aqueous interior (SOD1-liposomes) and free SOD1. SOD1-enzymosomes, unlike SOD1-liposomes, have as therapeutic effect decreasing liver damage in a rat liver ischemia/reperfusion model. As a result, SOD1-enzymosomes were shown to be a new and successful therapeutic approach for oxidative stress-associated inflammatory diseases [56].

A highly efficient SOD1-loaded vesicle targeting the mucosal tissue was produced by enzyme encapsulation into liposomes composed of soybean lecithin (SLT), SA, phosphatidyl glycerol (PG) and $\mathrm{CHOL}$ with different charges. All types of liposomes were successfully coated with two types of low and medium molecular weight chitosans (CSs) that increased their mucoadhesive characteristics [57]. Superoxide dismutase attached to lecithin molecules was evaluated concerning the interaction with serum proteins and cells. The data indicated that the increased hydrophobicity of lecithinized SOD1 enhanced its association to both proteins and microdomains of plasma membrane. This formulation inhibited the SOD1 excretion, promoted its long-term retention in blood circulation and enhanced the cell internalization through endocytosis [58].

\subsubsection{Polymeric Systems}

Several engineered systems were developed by back, embedding into a suitable biodegradable and biocompatible polymer such as PEG. The most studied bacc in PEGylation is SOD1. The SOD1-PEG conjugation was studied both in vitro and in vivo models in comparison with the free enzyme, and the following observations were drawn: (i) at the blood vessel level, this system provides a higher resistance to oxidative stress, improves endothelium relaxation and inhibits lipid peroxidation; (ii) in the heart, it is at least as effective as native SOD1 in both reperfusion-induced arrhythmias and myocardial ischemia treatment; (iii) in the lung, it reduces the oxygen toxicity and Escherichia coli-induced lung, and (iv) in kidney and liver ischemia, both enzyme forms were found to ameliorate reperfusion 
damage [59]. Having in view all these positive findings, it is surprising that this system has not yet started clinical trials.

The neuroprotective efficacy of SOD1 loaded in poly(D,L-lactide co-glycolide) (PLGA) nanoparticles (NPs), in cultured human neurons in oxidative stress induced by hydrogen peroxide, was also investigated. The results showed that this system is compatible with human neurons and its neuroprotective effect is dose-dependent and enhanced in comparison with both SOD1 and PEG-SOD1. The mechanism of SOD1-NPs efficacy appears to be their stability and the better neuronal uptake of enzyme after encapsulation [60]. The same system was tested in order to assay their efficacy in a rat focal cerebral ischemia-reperfusion injury model. SOD1-NPs were administered during the reperfusion via the intracarotid route to maximize their localization in the brain. The SOD1-NPs maintained blood brain barrier (BBB) integrity, thereby preventing edema, reducing the level of ROS and protecting the neurons from apoptosis [61].

SOD1 cross-linked to a cationic block copolymer, methoxy-poly(ethylene glycol)-block-poly(L-lysine hydrochloride) (PEG-pLL50) retains catalytic activity, has a narrow size distribution and a low cytotoxicity. This carrier has a prolonged ability to scavenge ROS production in cultured brain microvessel endothelial cells and central neurons. Moreover, in vivo it decreases the ischemia/reperfusion-induced tissue injury and improves sensorimotor functions in a rat middle cerebral artery occlusion (MCAO) model after a single i.v. injection [62]. This enzyme was also electrostatically attached to a synthetic poly(ethyleneimine)epoly(ethyleneglycol) (PEIePEG) polymer to form a polyion complex (SOD1 nanozyme). Intracarotid injection of this nanozyme into rabbits significantly inhibited the angiotensin II (AngII) intra-neuronal signaling [63].

In order to enhance in vitro viability and function of isolated neonatal pancreatic porcine cell clusters (NPCCs), SOD1 was co-cultured with PLGA microspheres (MS) that slowly releases the enzyme. This system significantly improved the morphology, viability and function of the incubated NPCCs, and the slow SOD1 release could contribute to overcome the scarcity of transplant in patients with type 1 diabetes mellitus (T1DM) [64]. A modified method was used for both PLGA and poly(D,L-lactide) (PLA) MS preparation together with mannitol, trehalose, and PEG400 co-encapsulation for SOD1 stabilization. In vitro activity retention was evaluated by both nicotinammide adenine dinucleotide (NAD) oxidation and $\mathrm{H}_{2} \mathrm{O}_{2}$ consumption assays. SOD1 encapsulation efficiency resulted in 30 to $34 \%$ for PLA MS and up to 51\% for PLGA MS. SOD1 in vitro activity was preserved in all systems and was better stabilized in PLGA MS [65].

Another efficient system was developed by SOD1 encapsulating in the aqueous space of some porous polymersomes obtained by coassembly of poly(ethylene glycol)-polybutadiene (PEG-PBD) and poly(ethylene glycol)-block-poly(propylene oxide)-block-poly(ethylene glycol) (PEG-PPO-PEG). In vivo studies in the rats evidenced the polymersomes ability to prevent neuropathic pain associated with nerve root compression more effectively in comparison with free enzyme [66].

Two cationic block copolymers poly(ethylene glycol)-b-poly(L-lysine) (PEG-PLL) and PEG-b-poly(aspartate diethyltriamine) (PEG-DET) were engineered for chronic dosage of SOD1. These systems are well-tolerated by brain microvessel endothelial/neuronal cells and reduce the infarct volumes in a mouse model of ischemic stroke [67-69].

Besides SOD1, a series of other bacc species were embedded into polymeric matrix. Among these, nanogel composed of $\mathrm{N}$-[3-(dimethylamino)-propyl]methacrylamide (NDPMA) and sodium copper chlorophyllin (SCC) was synthesized and studied as a nanocarrier for photothermal therapy. The positively charged NDPMA at tertiary amine groups could facilitate the nanogel access into the cells through electrostatic attractions. The photothermal effect of SCC-containing nanogel via green laser exposure generated a mortality enhancement by $60 \%$ in the murine fibroblast (L929) cell line [70]. The SCC was also incorporated into a thermo-responsive polymeric nanogels formed by $\mathrm{N}$-isopropylacrylamide and $\mathrm{N}$-(hydroxymethyl)acrylamide copolymerization. The combination of hyperthermia and temperature-induced drug release via green laser irradiation greatly enhanced 
cell mortality of L929 cells to a maximal extent [71], and as a result, such a system could have a great potential in antitumor therapy.

The complex [Cu(dttct)] (16) (dttct is dibenzo[e,k]-2,3,8,9-tetraphenyl-1,4,7,10-tetraaza-cyclododeca1,3,7,9-tetraene) embedded within a poly(vinyl chloride) (PVC) was used for catalytic generation of nitric oxide in the presence of nitrite and ascorbic acid as reducing agent. This system showed an effectively control in both the formation and dispersion of nitrifying bacteria biofilm [72]. This complex immobilized together with [Fe( $\mathrm{dttct})]$ onto the same matrix composed of a system able to generate nitric oxide $(\mathrm{NO})$ from endogenous nitrite through $\mathrm{Cu}(\mathrm{II})$ conversion to active $\mathrm{Cu}(\mathrm{I})$. Besides nitrifying bacteria biofilm dispersion, the antibiofilm activity of these material was evidenced against Bacillus species [73].

The slow release of $\mathrm{Cu}$ (II) from $\left[\mathrm{Cu}_{3}(\mathrm{btc})_{2}\right](\mathbf{1 7})\left(\mathrm{H}_{3}\right.$ btc: benzene tricarboxylic acid) NPs embedded in an antioxidant poly-(polyethyleneglycol citrate-co- $\mathrm{N}$-isopropylacrylamide) (PPCN) hydrogel was set up. Such a system reduced the $\mathrm{Cu}(\mathrm{II})$ toxicity and enhanced the wound healing process for diabetic mice by promoting a plethora of processes such as cell migration, angiogenesis and collagen deposition [74]. This compound, embedded in PVC, reduced the bacterial attachment of both S. aureus and E. coli strains [75].

Polyaniline nanoshuttles coated with polyethylene glycol (PEG) and codoped with both $\mathrm{Cu}(\mathrm{II})$ and vincristine were developed as multifunctional, positive charged and long-circulating systems. These characteristics explain their higher accumulation in human oral epithelial carcinoma vincristine-resistant tumors (KBV) that further improved the efficacy of tumor theranostics, such as those using chemotherapy and photothermal therapy [76]. The $\left[\mathrm{Cu}(\mathrm{ddc})_{2}\right](\mathbf{1 3})$ moiety coordinated to carboxylic groups from poly(ethylene glycol)-b-poly(ester-carbonate) generated a highly stable system able to inhibit A549 cells proliferation both in vitro and in vivo [77]. The interest for this bacc is generated by the fact that dsf exhibits an excellent in vitro antiproliferative activity mediated by (13) as its metabolite.

The $\mathrm{Cu}$ (II) complex with poly[2-( $\mathrm{N}$-oxide- $\mathrm{N}, \mathrm{N}$-dimethylamino)ethyl methacrylate] (OPDMA) is a water-soluble zwitterion that can deliver metallic ions into tumor tissues, and was developed in order to potentiate the dsf antitumor efficacy [78]. A delivery system of $\left[\mathrm{Cu}(\mathrm{dpphen})(\mathrm{imc})_{2}\right](\mathbf{1 8})$ (dpphen is 4,7-diphenyl-1,10-phenanthroline, Himc is indomethacin) with methoxy poly(ethylene glycol)-b-poly(D,L-lactic-co-glycolic) acid (PEGPLGA) copolymer exhibits low toxicity and ability to selectively kill breast cancer stem cells over bulk ones. The cytotoxic effect comes from both intracellular ROS generation and cyclooxgenase-2 (COX2) inhibition [79].

A series of water soluble polymer copper(II) complexes (pcc) were obtained by some species with aromatic amine ligand coordination to the nitrogen atoms from branched polyethyleneimine (BPEI) and tested either for antitumor or for antimicrobial activity. Polyethyleneimine (PEI) is a cationic polymer studied as an alternative to liposomal routes of gene delivery [80]. This polymer acts as chelating agent, has good water solubility, a high number of functional groups and stability [81-85].

The systems [Cu(phen)(L-Thr)(BPEI) $] \mathrm{ClO}_{4} \cdot 2 \mathrm{H}_{2} \mathrm{O}$ (19) [81] and [Cu(phen)(L-phe)(BPEI)] $\mathrm{ClO}_{4} \cdot 4 \mathrm{H}_{2} \mathrm{O}$ (L-Thr: L-threonine, L-phe is L-phenylalanine) (20) [82], with various degree of copper(II) coordinated in the polymer matrix, were prepared and characterized. Studies concerning their binding abilities to calf thymus DNA (CT DNA) has been investigated, and the results indicated that the copper(II) content in the polymer backbone have a marked effect on the binding affinity. These pcc showed a good antimicrobial activity against some bacteria and fungi, comparable with that of standard drugs ciprofloxacin and clotrimazole, respectively. On the other hand, the systems $\left[\mathrm{Cu}(\text { phen })_{2}(\mathrm{BPEI})\right] \mathrm{Cl}_{2} \cdot 4 \mathrm{H}_{2} \mathrm{O}(\mathbf{2 1})$ [83] and [Cu(bpy) $\left.{ }_{2}(\mathrm{BPEI})\right] \mathrm{Cl}_{2} \cdot 4 \mathrm{H}_{2} \mathrm{O}$ (bpy is 2,2'-bipyridine) (22) [84,85], besides good antimicrobial activity, exhibited cytotoxicity against human lung cancer cells (NCI-H460). Cytological changes, such as chromatin fragmentation, binucleation, cytoplasmic vacuolation, nuclear swelling, cytoplasmic blebbing as well as late apoptosis and/or necrosis, were also observed during this experiments. The presence of multiple copper(II) complex moieties and free NH groups, in a single polymer molecule, enhanced the binding ability of these species to DNA through electrostatic, van der Waals and hydrogen bonding and/or intercalation [81-85]. 
The chemical resistance, low cost and versatile properties of polypropylene (PP) make it an attractive polymer for medical applications. A PP film functionalized with glycidyl methacrylate as a spacer arm and iminodiacetate moiety as a chelating group for $\mathrm{Cu}(\mathrm{II})$ has an anti-adhesive effect in case of E. coli [86]. A series of 2,6-pyridinedicarboxylate-based polyesters employing several diols with different aliphatic chain were synthesized and complexed with copper(II). The composites were tested for their antibacterial potential and were found to effectively resist $P$. aeruginosa attachment and colonization [87]. Additionally, the $\mathrm{Cu}\left(\mathrm{OH}_{2}\right)_{4}$ moiety was used to link together the systems obtained by castor oil phosphorylation. The generated polymer exhibits a good antibacterial activity against B. cereus and E. coli strains [88].

Chlorophyllin was encapsulated together with CdSe/ZnS as quantum dots into PLGA. This coformulation allows the generation of ROS upon excitation both in an aqueous medium and in cells, thus exhibiting potential in photodynamic therapy [89]. Some natural polymeric materials, such as polysaccharides (chitosan, hyaluronic acid, sodium alginate, cellulose) and proteins (sponge skeleton, albumin), have been used in recent years for bacc incorporation. Their useful features, which attracted attention, include low cost, biodegradability, renewability and high compatibility with human body [5].

Chitosan (CS) is a polyglucosamine with chelating abilities, as well as antimicrobial and hemostatic activity and cytocompatibility and mucoadhesion ability [90]. By CS mixing with chlorophyllin, an insoluble salt-like material was obtained. This system has the ability to efficiently trap polycyclic compounds such as heterocyclic amines and aflatoxin $B_{1}$, thus suppressing their mutagenic and carcinogenic behavior [91]. The SOD1 encapsulated CS microspheres were prepared by changing both $\mathrm{pH}$ and PEG addition, and it was observed that the protein activity remained within acceptable limits after the release of these formulations [92].

A water soluble complex of $\mathrm{Cu}$ (II) with chitosan have the ability to interact with DNA in two steps, consisting of electrostatic interaction and intercalation into the base pair [93]. On the other hand, chitosan was derivatized by condensation with salicylic aldehyde, and $\mathrm{Cu}$ (II) was coordinated into the Schiff base site. The nanoparticles of this system interact also with DNA via electrostatic interaction, while the aromatic moieties are able to intercalate. Moreover, this macromolecular complex inhibited the liver cancer (SMMC-7721) cell line, its activity being enhanced in comparison with both CS and free CS-Schiff-base [94].

Some $\mathrm{Cu}\left(\mathrm{OH}_{2}\right) \mathrm{X}(\mathbf{2 3})\left(\mathrm{X}\right.$ is $\left.\mathrm{CH}_{3} \mathrm{COO}\right)$ and (24) $\left(\mathrm{X}\right.$ is $\left.\mathrm{ClO}_{4}\right)$ moieties with Schiff base formed by CS derivatization with 2-hydroxy-3-metoxybenzaldehyde were tested in vitro against chronic myelogenous leukemia (K562) and osteosarcoma cancer (MG-63) cell lines. The good activity observed was related to an apoptotic effect [95]. On the other hand, Casiopein III-ia (8) loaded into CS nanoparticles increases the life span in mice transplanted with melanoma (B16) tumor cells [96]. The fibrous scaffolds obtained by homogeneous blend of copper(II)-CS complex and polycaprolactone generates a significant increase in the secretion of vascular endothelial growth factor (VEGF), a factor that can have high impact on endothelial cells, guiding angiogenesis both ex vivo and in vivo [97].

An antibacterial film composed of $\mathrm{CS}$ and $\left[\mathrm{Cu}_{3}(\mathrm{btc})_{2}\right](\mathbf{1 7})$ species has the ability to slow release copper ions, reduced cytotoxicity and antibacterial activity against E. coli and S. aureus strains. Furthermore, in vivo results on mice wounds infected with $S$. aureus revealed that this film could simultaneously kill bacteria and promote vessel regeneration, resulting in an enhanced wound closure rate during the local infection therapy process [98]. Some copper(II)-CS complexes were fabricated via in situ precipitation and tested on mouse embryonic fibroblasts and both S. carnosus and E. coli strains. Combined cells analysis and bacterial studies identified a threshold concentration at which the material shows antibacterial properties without significantly affecting the fibroblast viability [99]. Copper(II) complexes with CS functionalized with a Schiff base derived from amino benzoic acid and acetyl acetone was developed and tested on Phytophthora capsici Leonian. The results suggest that the system causes mitochondrial injury with enhanced ROS and reduced ATP levels, thereby killing this fungus [100]. 
Table 1. Examples of biologically active $\mathrm{Cu}(\mathrm{II})$ complexes embedded in organic matrix.

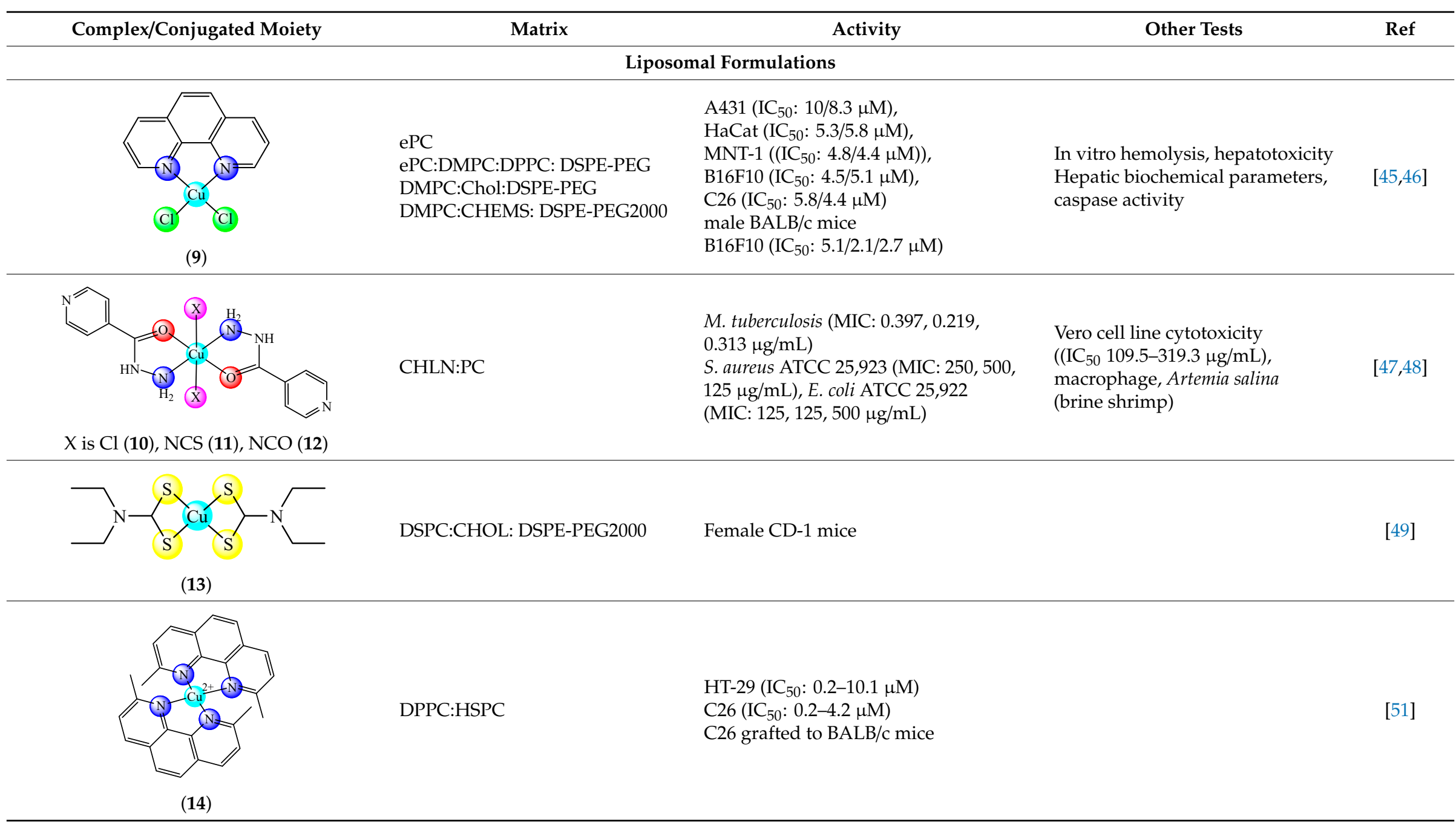


Table 1. Cont

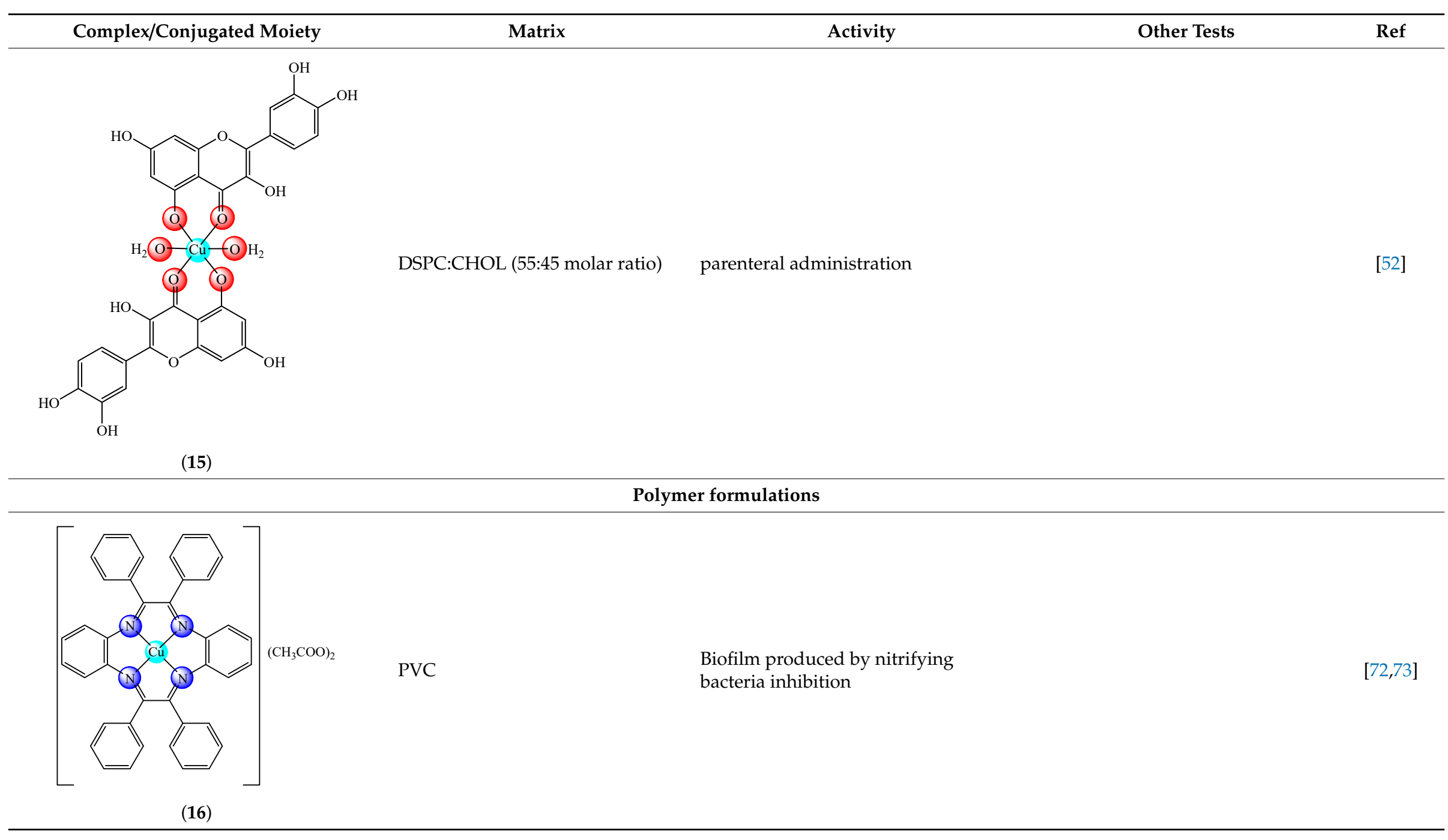


Table 1. Cont.

\begin{tabular}{|c|c|c|c|c|}
\hline Complex/Conjugated Moiety & Matrix & Activity & Other Tests & Ref \\
\hline & $\begin{array}{l}\text { PPCN } \\
\text { PVC }\end{array}$ & $\begin{array}{l}\text { Wound healing in diabetic mice } \\
\text { Biofilm of S. aureus, E. coli inhibition }\end{array}$ & $\begin{array}{l}\text { Cell migration, angiogenesis and } \\
\text { collagen deposition }\end{array}$ & {$[74,75]$} \\
\hline \multicolumn{5}{|l|}{ Basic moiety in (17) } \\
\hline & PEGPLGA & $\begin{array}{l}\text { HMLER }\left(\mathrm{IC}_{50}: 7.38 \mu \mathrm{M}\right) \\
\text { HMLERshEcad }\left(\mathrm{IC}_{50}: 2.21 \mu \mathrm{M}\right)\end{array}$ & $\begin{array}{l}\text { ROS production } \\
\text { COX-2 inhibition }\end{array}$ & [79] \\
\hline & BPEI & $\begin{array}{l}\text { S. aureus, B. subtilis, E. coli, P. aeruginosa, } \\
\text { C. albicans (diameter of inhibition zone) }\end{array}$ & CT DNA interaction & [81] \\
\hline 9) & & & & \\
\hline
\end{tabular}


Table 1. Cont.

\begin{tabular}{|c|c|c|c|c|}
\hline Complex/Conjugated Moiety & Matrix & Activity & Other Tests & Ref \\
\hline & BPEI & $\begin{array}{l}\text { S. aureus, B. subtilis, E. coli, } \\
\text { P. aeruginosa, C. albicans } \\
\text { (diameter of inhibition zone) }\end{array}$ & CT DNA interaction & [82] \\
\hline & BPEI & $\begin{array}{l}\text { S. aureus, B. subtilis, E. coli, } \\
\text { P. aeruginosa, C. albicans } \\
\text { (diameter of inhibition zone) } \\
\text { NCI-H460 cells }\left(\mathrm{IC}_{50}: 13.2 \mu \mathrm{g} / \mathrm{mL} \text { ) }\right.\end{array}$ & CT DNA interaction & [83] \\
\hline & BPEI & $\begin{array}{l}\text { S. aureus, B. subtilis, E. coli, } \\
\text { P. aeruginosa, C. albicans } \\
\text { (diameter of inhibition zone) } \\
\text { NCI-H460 } \\
\left(\mathrm{IC}_{50}: 90-95 \mu \mathrm{g} / \mathrm{mL}\right)\end{array}$ & CT DNA interaction & {$[84,85]$} \\
\hline (O) $\mathrm{H}_{2}$ & $\begin{array}{l}\text { Chitosan Schiff base with } \\
\text { 2-hydroxy-3-metoxybenzaldehyde }\end{array}$ & $\begin{array}{l}\mathrm{K} 562\left(\mathrm{IC}_{50}: 1 \mu \mathrm{g} / \mathrm{mL}\right) \\
\mathrm{MG}-63\left(\mathrm{IC}_{50}: 25 \mu \mathrm{g} / \mathrm{mL}\right)\end{array}$ & Apoptosis studies & [95] \\
\hline (23) $X$ & & & & \\
\hline
\end{tabular}

Branched polyethyleneimine (BPEI), cholesteryl hemisuccinate (CHEMS), choline (CHLN), cholesterol (CHOL), dimyristoyl phosphatidylcholine (DMPC),

1,2-dipalmitoyl-sn-glycero-3-phosphatidylcholine (DPPC), dipalmitoylphosphoethanolamine-N-[methoxy(polyethyleneglycol)-2000] ammonium salt (DPPE-PEG2000),

1,2-distearoyl-sn-glycero-3-phosphocholine (DSPC), distearoyl phosphatidylethanolamine (DSPE), hydrogenated soybean phosphatidylcholine (HSPC), phosphatidylcholine (PC), poly(ethylene glycol (PEG), methoxy poly(ethylene glycol)-b-poly(D,L-lactic-co-glycolic) acid (PEGPLGA), poly-(polyethyleneglycol citrate-co- $N$-isopropylacrylamide) (PPCN),

polyvinyl chloride (PVC). Chronic myelogenous leukemia (K562), human colorectal adenocarcinoma (HT-29), human epidermoid carcinoma (A431), human keratinocytes (HaCaT), human melanotic neuroectodermal tumor (MNT-1), osteosarcoma (MG-63), mammary epithelial cell lines (HMLER, HMLERshEcad), murine colon cancer cells (C26), murine melanoma (B16F10), U251MG (glioblastoma cell line). 
Hyaluronic acid (HA), a linear polysaccharide found in physiological fluids, is another species able to coordinate copper(II) and promote an angiogenic response through endothelial cells mobilization [101]. A hydrogel based on HA with $\mathrm{Cu}(\mathrm{II})$ coordinated through the amidic and carboxylate oxygen atoms, evaluated in vitro by using fibroblast (3T3) cells and in vivo on rats, showed proangiogenic activity by stimulating the growth of new capillary vessels without any inflammatory reaction [102].

The complex $[\mathrm{Cu}(\mathrm{ppt})]_{\mathrm{n}}\left(\mathrm{H}_{2} \mathrm{ppt}\right.$ is polymerized-p-phenylenediamine-5,10,15,20-tetra-(4-aminophenyl) porphyrin) embedded in HA generated a multifunctional nanoplatform with a good antitumor activity potentiated by a synergistic photo-/chemodynamic and immunotherapy. This system exhibits antimetastatic activity, ability to suppress the tumor growth as well as immune response activation in colon carcinoma (CT26) tumor cells both in vitro and mice grafted or injected ones. It was observed that the light excitation enhanced the therapeutic effect that was related to ROS generation through Fenton-like reactions [103].

An amylopectin modified with diethylenetriaminepentaacetic acid residues for copper chelation was prepared as hydrogel. The product conjugated with basic fibroblast growth factor (bFGF) has the ability to regulates its controlled release due to hydrogel biodegradation, thus resulting in a prolonged neovascularization in mice. The $\mathrm{Cu}$ (II) decreased the rate of bFGF release, thus showing antitumor potential [104]. The same team developed a $\mathrm{Cu}(\mathrm{II})$ complex with dextran modified with diethylenetriaminepentaacetic acid that enabled tumor necrosis factor $\alpha$ (TNF) to coordinative conjugate to this system. Its i.v. administrations suppressed tumor growth in tumor-bearing mice by a higher TNF tumor accumulation [105].

Sodium alginate (SAG), a linear polysaccharide present in the cell walls of various seaweeds, has along the backbone several hydroxyl and carboxyl groups that can be functionalized. This species was successfully used as oral delivery systems [106]. The micelles composed of $\mathrm{Cu}$ (II) complex with this polysaccharide derivatized with $N$-(2-hydroxyethyl)- $N, N$-dimethyldodecan-1-aminium bromide cationic surfactant was evaluated against several bacteria (B. subtilis, S. aureus, E. coli and Pseudomonas aeruginosa) and fungi (C. albicans and Asperigllus niger). The system exhibits an enhanced antimicrobial activity on all tested strains in comparison with derivatized SAG and its Co(II) complex but lower in comparison with the $\mathrm{Zn}(\mathrm{II})$ species [107].

Cyclodextrins (CD), as cyclic polysaccharide containing D-glucopyranose units linked with $\alpha-1,4$-glucosidic bonds, are classified as $\alpha, \beta$ or $\gamma$ depending on the number of such units from their structure [108] Their ability to be functionalized and to retain complexes into their cavity was exploited in order to develop useful carriers. A hydrogel film composed of carboxymethyl cellulose $(\mathrm{CMC})$, cellulose nanocrystals (CNC) and hydroxypropyl $\beta$ cyclodextrin $(\mathrm{HP}-\beta-\mathrm{CD})$ cross-linked by citric acid was prepared and studied for the controlled release of the neohesperidin-copper(II) complex. The system exhibits cell compatibility and a low cytotoxicity, and as a result can be studied as a bacc delivery material with controlled release [109]. The soluble complex [Cu(chz)Cl] (Hchzis 6-hydroxychromone-3-carbaldehyde-( 3 '-hydroxy)benzoylhydrazone) was spontaneously included in heptakis-2,6-O-dimethyl- $\beta$-cyclodextrin $(\mathrm{DM} \beta \mathrm{CD})$ and the inclusion complex was proven to bind CT DNA in an intercalative mode [110].

Another biodegradable and biocompatible polysaccharide, cellulose acetate (CA) was functionalized with $\left[\mathrm{CuL}_{2} \mathrm{Cl}_{2}\right]$ ( $\mathrm{L}$ is 2-fluoropyridine) in order to obtain microfibers via the electrospinning technique. The obtained system was found to have considerable antibacterial effect against $E$. coli and MRSA [111]. Copper(II) was also coordinated to a cellulose-based material functionalized at aldehyde groups by condensation with glycine. This system enhanced the antibacterial properties of the cellulose fibers against S. aureus and E. coli strains [112]. The material, consisting of Hippospongia communis sponge skeleton and SCC, reduced the growth of S. aureus in dependence with the SCC content. It was also observed that the chlorophyllin adsorption on $H$. communis sponge skeletons varies as a function of the $\mathrm{pH}$ and ionic strength [113]. 
An SOD1 carrier was obtained by enzyme conjugation with both mouse vascular cell adhesion molecule 1 (VCAM-1)-targeted nanobodies and an albumin-binding arm (VCAM/ALB8). The bispecific system VCAM/ALB8 was superior in comparison with VCAMelid in enhancing both the circulation time and organ targeting of the enzyme [114]. Other systems were developed by SOD1 conjugation with ferritin [115], with antibodies to plasmalemmal vesicle-associated protein (Plvap) [116] or to platelet endothelial cell adhesion molecule (PECAM) [117] for a targeted delivery of enzymatic cargo to endothelial caveolae-derived endosomes.

The nanosystem formed by bovine serum albumin (BSA), $\mathrm{Cu}$ (II) and 5-nitro-8-hydroxyquinoline, a known anticancer agent, was developed as a selective tumor targeting formulation. Its cytotoxic effect was enhanced in comparison with components in mouse breast (4T1), human non-small cell lung (A549) and human cervical (HeLa) cancer cells and moreover without a systemic toxicity [118].

\subsubsection{Dendrimers}

Dendrimers are highly branched three-dimensional macromolecules with a globular and monodisperse structure and groups able to coordinate metallic ions, properties that afford their applications as $\mathrm{Cu}(\mathrm{II})$ carriers for antitumor and antimicrobial systems, including for biofilm formation prevention. A proper selection of dendritic scaffold, generation type and ligand attached to $\mathrm{Cu}$ (II) can lead to a potent activity that can overcome the limitations of traditional therapies [119]. The main type used for $\mathrm{Cu}$ (II) delivery are nitrogen-, phosphorus- and silicone-based dendrimers.

A second-generation poly(propylene imine) dendrimer modified with acridine and loaded with $\mathrm{Cu}$ (II) showed a good antimicrobial activity on B. cereus and C. lipolytica and low cytotoxicity against the HEp-2 cell line. Moreover, modified cotton fabrics with this dendrimer prevent biofilm formation in case of B. cereus and P. aeruginosa strains but do not exhibit cytotoxicity against the Human epithelial type 2 (HEp-2) cell line [120].

A first generation polyamidoamine (PAMAM) dendrimer functionalized with 1,8-naphthalimide units was synthesized, loaded with different amount of $\mathrm{Cu}$ (II) (25) (Figure 2) and attached on the cotton surface. Both materials had the ability to reduce bacterial growth and prevent the biofilm formation in case of B. subtilis, B. cereus and Acinetobacter johnsonii, the best effect being observed on the last strain [121]. On the other hand, the second generation PAMAM dendrimer modified with 4-(N,N-dimethylaminoethyloxy)-1,8-naphthalimide and conjugated with cis- $\mathrm{Cu}\left(\mathrm{NO}_{3}\right)_{2}$ moiety (26) (Figure 2) was deposited on cotton fabric, and this material was found to be active against biofilm produced by B. cereus, P. aeruginosa and C. lipolytica strains [122].

Among the phosphorus-containing dendrimers, those bearing iminopyridine (IP) terminal groups have good ability to coordinate $\mathrm{Cu}$ (II) [123]. As a result, some phosphorus multidentate dendrimers of generation $\mathrm{Gn}$ ( $n=1$ to 3 ) decorated with IP and coordinated to $\mathrm{CuCl}_{2}$ moiety were developed and tested for antiproliferative activity against a panel of tumor cell lines. The complex with a system derived from $N$-(pyridin-2-ylmethylene)ethanamine exhibits a very potent antiproliferative activity $(>80 \%)$ against epidermal carcinoma (KB) and leukemia (HL60) cell lines [124]. The mechanism of action consists of the proapoptotic protein Bax activation pathway [125]. The EPR studies evidenced the high stability of G3 dendrimer functionalized with $N$-(di(pyridine-2-yl)methylene) ethanamine moiety in correlation with its good activity [126].

A third generation of phosphorus dendrimer decorated with (IP) groups as $\mathrm{Cu}$ (II) complex was developed as an agent with enhanced tumor accumulation. This system inhibits the pancreatic cancer (SW1990) cell line through the apoptosis activation via up- or downregulation of some genes [127]. Metallophosphorus dendrimer (G3, 48 terminal groups) with IP units was prepared with both Au(III) and $\mathrm{Cu}(\mathrm{II})$, and a synergistic effects of the two cations on the antimicrobial activity was observed in case of ATCC standard strains S. aureus, E. coli, P. aeruginosa and C. albicans as well as against drug-resistant clinical isolates $S$. aureus, Enterococcus faecalis and C. glabrata. The minimal inhibitory concentration (MIC) values fall in a concentration range of $3.5-500 \mathrm{mg} / \mathrm{L}$ and the most sensitive strain was E. coli [128]. 


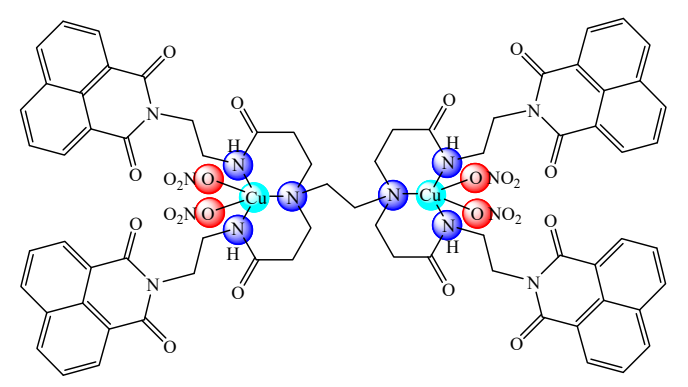

(25)

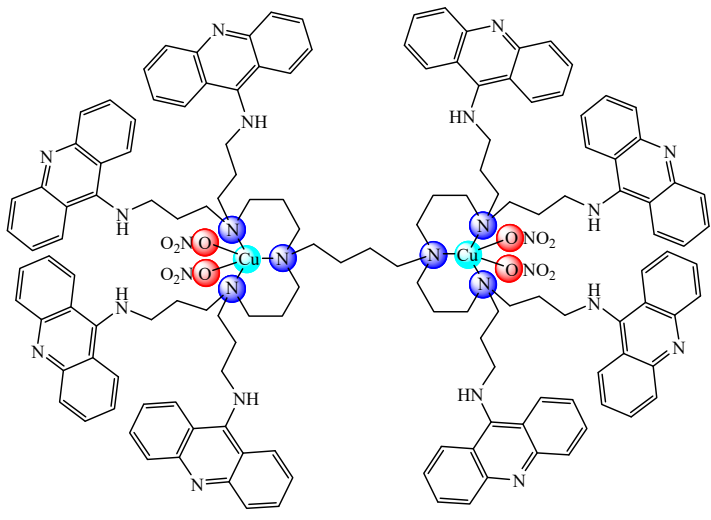

(26)

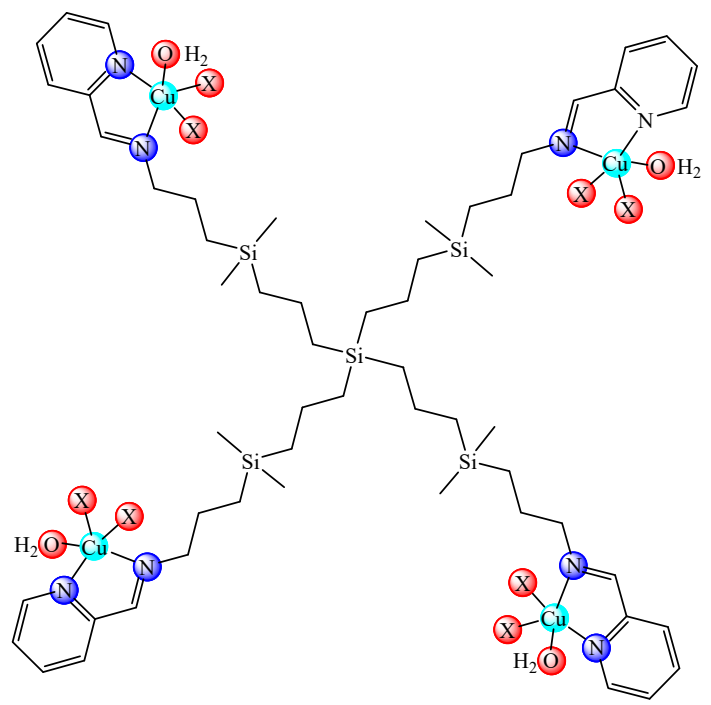

(27) $\left(\mathrm{X}\right.$ is $\left.\mathrm{ONO}_{2}\right),(28)(\mathrm{X}$ is $\mathrm{Cl})$

Figure 2. Bioactive dendrimeric complexes (25)-(28).

A G1 carbosilane dendrimer decorated with IP groups and conjugated with $\mathrm{Cu}\left(\mathrm{OH}_{2}\right)\left(\mathrm{ONO}_{2}\right)_{2}$ moiety was developed as water-soluble, stable and potent bacteriostatic and bactericide species against planktonic S. aureus and E. coli strains. Furthermore, it prevents the formation of S. aureus biofilm at a low concentration and is not hemotoxic [119]. The corresponding system with $\mathrm{Cu}\left(\mathrm{OH}_{2}\right) \mathrm{Cl}_{2}$ moiety exhibits a moderate cytotoxicity in myeloid (U937) cancer cells. The system induces cell death through the mitochondria-lysosome system as well as vacuole formation through autophagy [129]. A comparative study of such $\mathrm{G} 1$ and $\mathrm{G} 2$ dendrimers conjugated with $\mathrm{Cu}\left(\mathrm{OH}_{2}\right) \mathrm{X}_{2}$ (27) $\left(\mathrm{X}\right.$ : is $\left.\mathrm{ONO}_{2}\right)$ and $(\mathbf{2 8})(\mathrm{X}$ is $\mathrm{Cl})$ moieties (Figure 2$)$ revealed that the increase in generation and changing nitrate with chloride, produced an increased in vitro cytotoxic effect in cervix (HeLa), normal and resistant breast cancer (MCF7 and HCC1806), advanced prostate cancer (PC3) and colorectal tumor (HT29) cell lines. It is worth to mention the good activity against the resistant tumor cells with $\mathrm{IC}_{50}$ values below $3.4 \mu \mathrm{M}$ in PC3 and below $1.9 \mu \mathrm{M}$ in HCC1806. Moreover, one of the nitrate derivatives both inhibited proliferation and decreased the adhesion to collagen type-I PC3 cells in an experimental ex vivo mice model of human prostate cancer [130]. Similar systems from G0 to G2 modified with $\mathrm{Cu}\left(\mathrm{OH}_{2}\right)\left(\mathrm{NO}_{3}\right)_{2}$ or $\mathrm{Cu}\left(\mathrm{OH}_{2}\right) \mathrm{Cl}_{2}$ moieties were also studied concerning their cytotoxic properties toward healthy peripheral blood mononuclear cells (PBMC) and leukemia (1301 and HL-60) cancer cell lines. The cytotoxicity assays showed that all compounds were more active on 1301 in comparison with HL-60 cell line with a low toxicity on PBMC [131].

Carbosilane G1 copper (II) metallodendrimers modified with Schiff base and loaded with small interfering RNA (siRNA) were developed as an antitumor strategy. Cell viability assays performed 
by flow cytometry indicated interactions between these dendrimers and pro-apoptotic siRNAs genes in MCF-7 [132].

\subsection{Inorganic Based Carriers}

The bacc $\left[\mathrm{Cu}_{3}(\mathrm{btc})_{2}\right](\mathbf{1 7})$, embedded in titanium oxide film and 316L stainless steel as materials with a good biocompatibility with both endothelial and macrophages cells, inhibited the bacterial adhesion of both $S$. aureus and E. coli strains [75]. The same species immobilized on titanium foils exhibited ideal $\mathrm{NO}$ release and a synergistic role of $\mathrm{NO}$ and $\mathrm{Cu}(\mathrm{II})$ in inhibiting platelet activation, suppressing macrophages adhesion and proliferation in order to reduce hyperplasia. The ex vivo and in vivo experiments indicated an enhancement of re-endothelialization and anti-hyperplasia by this immobilized coating with the potential for cardiovascular applications [133].

CSS was also embedded in hydrotalcite [134] or graphene oxide [135] in order to obtain materials with bactericidal effect. The hydrotalcite based system is active on E. coli, Enterobacter aerogenes, Salmonella enterica and S. aureus strains and exhibits a low toxicity [134]. In case of graphene oxide based nanomaterials functionalized with chlorophyllin and chlorophyllin-Zn(II), the last one exhibited the highest antibacterial activity against Escherichia coli. Further investigations show that the bacteria incubation with these nanomaterials caused cell death through cellular integrity loss [135].

SOD1 was covalently immobilized onto oxidized multiwalled carbon nanotubes (MwCNTs) by using a diimide activated amidation reaction. The obtained material produced a low level of ROS and an increased enzyme activity into human keratinocytes (HaCat) cells [136]. Mesoporous vaterite $\left(\mathrm{CaCO}_{3}\right)$ was also used as a vector for SOD1 delivery for an ophthalmological formulation [137].

The [ $\left.\mathrm{CuL}_{2}\right]$ (HL is acetic acid, acetyl acetone) encapsulation into functionalized nanostructured titanium dioxide $\left(\mathrm{TiO}_{2}\right)$ provided porous nanoparticles with a promising in vitro antitumor activity and no significant toxic effect on rat glioma (C6 and RG2), human glioma (U373) and mouse melanoma (B16) cell lines [138].

Mesoporous silica (MSS) were also studied as inorganic drug-delivery systems due to their attractive properties, such as a high surface area, tunable pore/particle size/morphology, a very high chemical stability as well as an easy surface functionalization [139]. As a result, some examples of bacc embedded in MSS matrix have been reported. One of them was obtained by diamine functionalized MS combination with curcumin, $\mathrm{Cu}(\mathrm{II})$ and immobilized AgNPs, and showed an excellent photodynamic inactivation of antibiotic-resistant E. coli. The activity was assigned by a synergistic effect of $\mathrm{Cu}(\mathrm{II})$, silver and curcumin [140]. MSS functionalized stepwise with 3-aminopropyltriethoxysilane, 2-hydroxy-3-methoxybenzaldehyde and $\mathrm{Cu}$ (II) showed an inhibitory effect and growth retardation on S. aureus and bacteriostatic effect against E. coli [141]. MSS NPs containing a maleamato ligand was used to coordinate copper(II) ions and evidenced an improved activity against the same strain [142].

The SBA-15 (Santa Barbara Amorphous material 15) MSS grafted with triethoxysilylpropylmaleamic acid (maleamic) and triethoxy-3-(2-imidazolin-1-yl)propylsilane (imidazoline) was loaded with copper(II) in the presence of 5,5'-dimethyl-2,2'-bipyridine as an ancillary ligand. Although the material with maleamic acid contains a lower amount of $\mathrm{Cu}(\mathrm{II})$, it exhibits a higher activity against $S$. aureus and E. coli strains, properties related to ROS production and with the ability to interfere in both peptidoglycan synthesis and glutathione metabolism [143].

The SOD1 mimics, $\left[\mathrm{CuZn}(\text { dien })_{2}(\mu-\mathrm{Im})\left(\mathrm{ClO}_{4}\right)_{2}\right] \mathrm{ClO}_{4}$ and $\left[\mathrm{Cu}_{2}(\text { dien })_{2}(\mu-\mathrm{Im})\left(\mathrm{ClO}_{4}\right)_{2}\right] \mathrm{ClO}_{4}(\mathrm{Him}$ is imidazolate, dien is diethylenetriamine), were also encapsulated in MSS, and the obtained materials showed an improved anti-inflammatory activity [144].

An efficient targeted delivery platform based on folate-receptor was developed by $[\mathrm{Cu}(\mathrm{L})(\mathrm{dppz})]^{+}$ (LH is 2-[(2-dimethylaminoethylimino)methyl]phenol, coordinated ligand, dppz = dipyrido[3,2-a:2' $\left.3^{\prime} 3^{\prime}-\mathrm{c}\right]$ phenazine) encapsulation into MSS. This system exhibits selective accumulation and high cytotoxicity on breast cancer cells MCF-7 and MDA-MB-231 [145]. 


\subsection{Hybrid-Based Materials}

Among hybrid materials, some Ca-alginate (AG) systems with a porous carbonate cores were loaded with SOD1, and their efficacy in protection of the enzyme activity in simulated intestinal fluid with trypsin was demonstrated [146].

The gold nanoparticles modified with amine terminated PEG and decorated with biotin were studied as a delivery system for the [CuL] $\left(\mathrm{H}_{2} \mathrm{~L}\right.$ is diacetyl-bis(N4-methylthiosemicarbazone)) complex with specificity for cancer cells. The $\mathrm{Cu}$ (II) complex was attached to a linker containing disulfide bond loaded onto the gold nanoparticle surface. Both in vitro and in vivo studies proved the activity on HeLa cells, both free and xenograft in mice, with a 3.8-fold reduction in tumor volume during the treatment [147]. Copper(II) coordinated at glucosamine and $N$-acetylglucosamine groups of CS generated some coatings fabricated by electrophoretic deposition on a 316L stainless substrate. The test performed on $S$. aureus and E. coli evidenced the bacterial growth inhibition in the early stages of implantation without any cytotoxicity for all systems containing different amount of $\mathrm{Cu}$ (II) [148].

Among the magnetic nanoparticles, magnetite $\left(\mathrm{Fe}_{3} \mathrm{O}_{4}\right)$ has unique properties, such as low toxicity, superparamagnetism, high surface area, biocompatibility and a chemically modifiable surface. An organic-inorganic hybrid material based on magnetic mesoporous silica $\mathrm{Fe}_{3} \mathrm{O}_{4} @ \mathrm{MCM}-41$ was functionalized with $N$-(2-aminoethyl)-3-aminopropyltrimethoxysilane and grafted with a Schiff base for $\mathrm{Cu}$ (II) coordination. This material conjugated with streptomycin completely inhibited the growth of both S. aureus and E. coli, the effect being more prominent in the presence of a magnetic field [149].

\section{Conclusions}

Nowadays, the medical interest for copper complexes arises from their used as therapeutic agents in Menkes disease, inflammatory conditions, iron deficiency anemia or various skin conditions, or as drug candidates investigated in clinical trials for the efficacy in the treatment of amyotrophic lateral sclerosis or cancer. The small number of copper-based drugs that are in current use is a result of a reduced stability both in water and acidic environment and of an unfavorable balance between water solubility and lipophilicity. In order to overcome these problems, a series of biological active copper complexes were combined with a wide range of organic, inorganic or hybrid (organic-inorganic)-based carriers. The most studies were performed with known drugs, such as SOD1 and chlorophyllin, that were embedded both in organic and inorganic matrices. The association with both kinds of matrices have improved the pharmacological profile of drug; the most promising approach seems to be the liposomal embedding. Generally, the studies were performed for anti-inflammatory, antimicrobial and antitumor species. Important is that many formulations were either on biofilm embedded microorganisms or on resistant bacteria or tumor cells.

Author Contributions: Conceptualization, M.B., V.U. and R.O.; writing—original draft preparation, M.B., V.U. and R.O.; supervision, R.O. All authors have read and agreed to the published version of the manuscript.

Funding: This research received no external funding.

Conflicts of Interest: The authors declare no conflict of interest.

$\begin{array}{ll}\text { Abbreviations } & \\ \text { AG } & \text { alginate } \\ \text { ALB } & \text { albumin } \\ \text { AngII } & \text { angiotensin II } \\ \text { bacc } & \text { biologically active copper complexes } \\ \text { BBB } & \text { blood brain barrier } \\ \text { bFGF } & \text { basic fibroblast growth factor } \\ \text { BPEI } & \text { branched polyethyleneimine } \\ \text { bpy } & 2,2^{\prime} \text {-bipyridine }\end{array}$




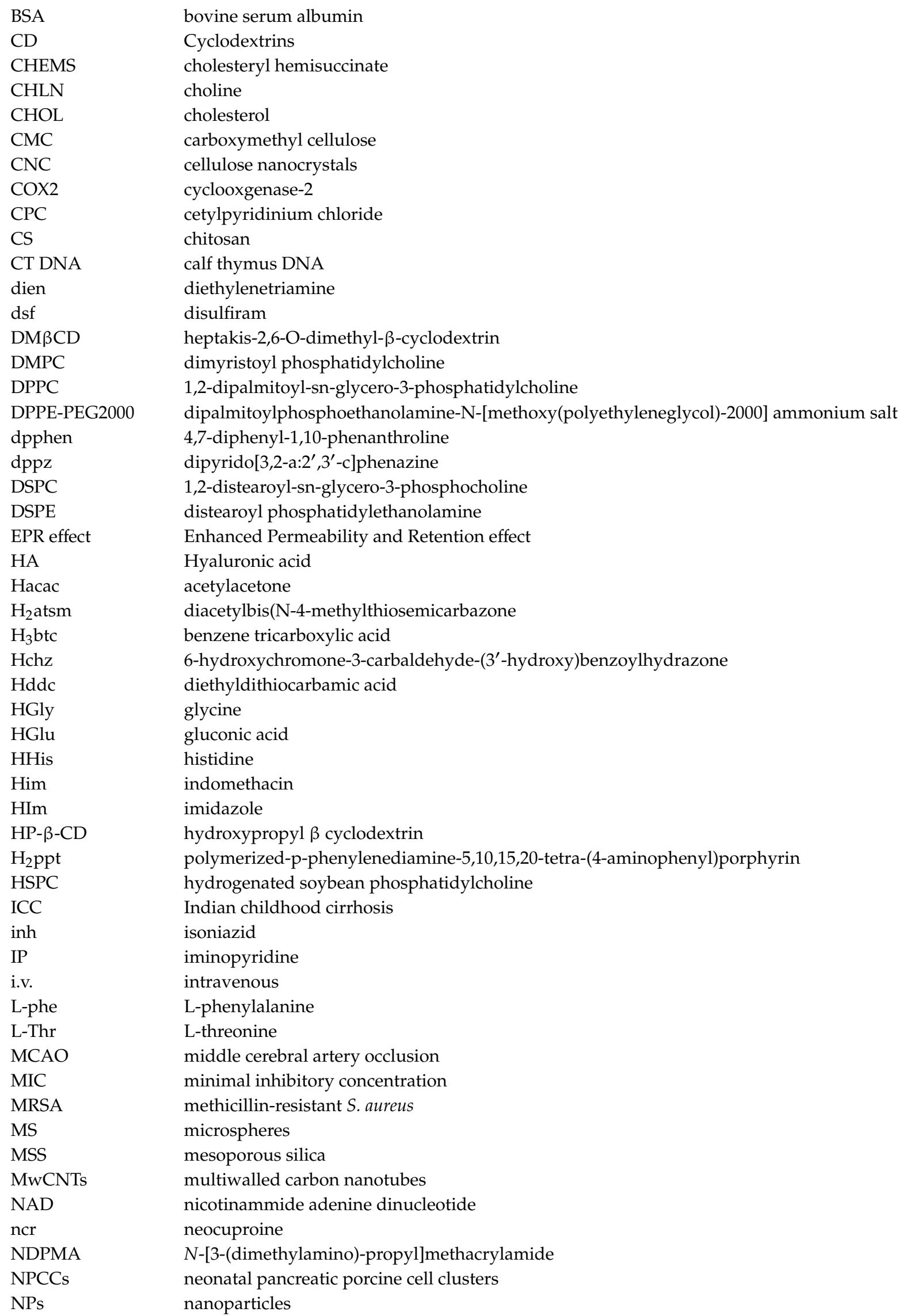




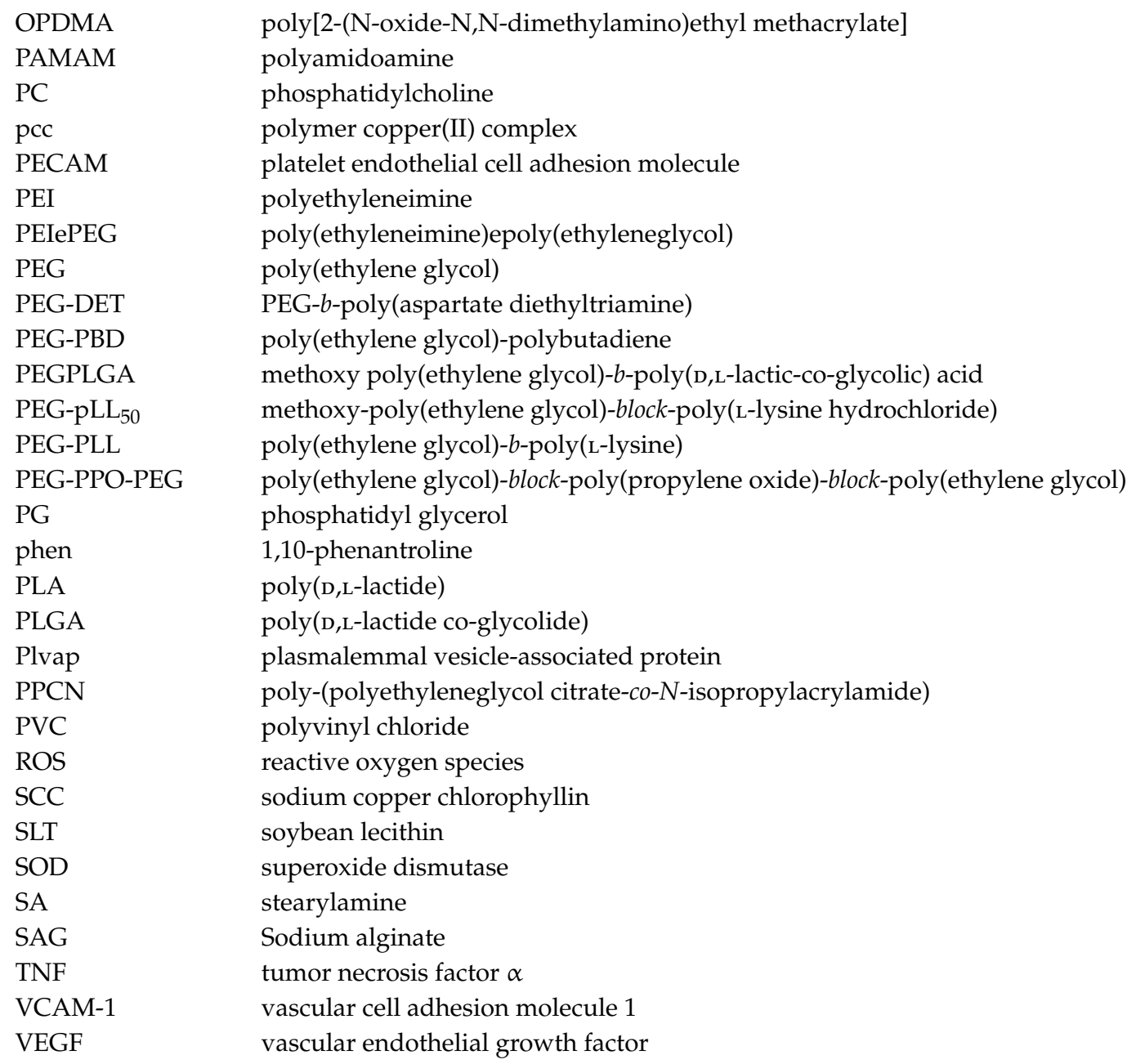

\section{References}

1. Dollwet, H.H.A.; Sorenson, J.R.J. Historic uses of copper compounds in medicine. Trace Elem. Med. 1985, 2, 80-87.

2. Ogata, R.; Chong, P.F.; Maeda, K.; Imagi, T.; Nakamura, R.; Kawamura, N.; Kira, R. Long surviving classical Menkes disease treated with weekly intravenous copper therapy. J. Trace Elem. Med. Biol. 2019, 54, 172-174. [CrossRef] [PubMed]

3. Bryszewska, M.A. Comparison Study of Iron Bioaccessibility from Dietary Supplements and Microencapsulated Preparations. Nutrients 2019, 11, 273. [CrossRef]

4. Myint, Z.W.; Oo, T.H.; Thein, K.Z.; Tun, A.M.; Saeed, H. Copper deficiency anemia: Review article. Ann. Hematol. 2018, 97, 1527-1534. [CrossRef]

5. Park, S.J.; Park, Y.M. Eco-dyeing and antimicrobial properties of chlorophyllin copper complex extracted from Sasa veitchii fiber. Polymer 2010, 11,357-362.

6. Zhang, J.; Wang, W.; Yang, F.; Zhou, X.; Jin, H.; Yang, P.-Y. Comparative proteomic analysis of drug sodium iron chlorophyllin addition to Hep 3B cell line. Analyst 2012, 137, 4287-4294. [CrossRef] [PubMed]

7. Tumolo, T.; Lanfer-Marquez, U.M. Copper chlorophyllin: A food colorant with bioactive properties? Food Res. Int. 2012, 46, 451-459. [CrossRef]

8. Mizushima, Y.; Hoshi, K.; Yanagawa, A.; Takano, K. Topical application of superoxide dismutase cream. Drugs Exp. Clin. Res. 1991, 17, 127-131.

9. Churilova, I.V.; Zinov'ev, E.V.; Paramonov, B.A.; Drozdova, Y.I.; Sidel'nikov, V.O.; Chebotarev, V.Y. Effect of Erysod (erythrocyte superoxide dismutase) on blood concentration of reactive oxygen species in patients with severe burns and burn shock. Bull. Exp. Biol. Med. 2002, 134, 454-456. [CrossRef] 
10. Yasui, K.; Baba, A. Therapeutic potential of superoxide dismutase (SOD) for resolution of inflammation. Inflamm. Res. 2006, 55, 359-363. [CrossRef]

11. Carillon, J.; Rouanet, J.-M.; Cristol, J.-P.; Brion, R. Superoxide Dismutase Administration, A Potential Therapy Against Oxidative Stress Related Diseases: Several Routes of Supplementation and Proposal of an Original Mechanism of Action. Pharm. Res. 2013, 30, 2718-2728. [CrossRef] [PubMed]

12. Kaur, N.; Sharma, A.K.; Shakeel, A.; Kumar, V.; Singh, A.; Gupta, A.; Suhag, D.; Rajput, S.K.; Mukherjee, M. Therapeutic implications of superoxide dismutase and its importance in kinase drug discovery. Curr. Top. Med. Chem. 2017, 17, 2495-2508. [CrossRef] [PubMed]

13. Sorenson, J.R. Cu, Fe, Mn, and Zn Chelates Offer a Medicinal Chemistry Approach to Overcoming Radiation Injury. Curr. Med. Chem. 2002, 9, 639-662. [CrossRef] [PubMed]

14. Kuo, M.T.H.; Beckman, J.S.; Shaw, C.A. Neuroprotective effect of CuATSM on neurotoxin-induced motor neuron loss in an ALS mouse model. Neurobiol. Dis. 2019, 130, 104495. [CrossRef]

15. Gracia-Mora, I.; Ruiz-Ramirez, L.; G6mez-Ruiz, C.; Tinoco-Mndez, M.; Mtirquez-Quifiones, A.; Romero-De Lira, L.; Marin-Hernandez, A.; Madas-Rosales, L.; Bravo-Gdmez, M.E. Knigth's move in the periodic table, from copper to platinum, novel antitumor mixed chelate copper compounds, casiopeinas, evaluated by an in vitro human and murine cancer cell line panel. Metal Based Drugs 2001, 43, 19-28. [CrossRef]

16. Huang, J.; Chaudhary, R.; Cohen, A.L.; Fink, K.; Goldlust, S.; Boockvar, J.; Chinnaiyan, P.; Wan, L.; Marcus, S.; Campian, J.L. A multicenter phase II study of temozolomide plus disulfiram and copper for recurrent temozolomide-resistant glioblastoma. J. Neuro-Oncol. 2019, 142, 537-544. [CrossRef]

17. Wang, T.; Gu, Z. Copper in Medicine: Homeostasis, Chelation Therapy and Antitumor Drug Design. Curr. Med. Chem. 2006, 13, 525-537. [CrossRef]

18. Tisato, F.; Marzano, C.; Porchia, M.; Pellei, M.; Santini, C. Copper in Diseases and Treatments, and Copper-Based Anticancer Strategies. Med. Res. Rev. 2010, 30, 708-749. [CrossRef]

19. Hordyjewska, A.; Popiołek, Ł.; Kocot, J. The many "faces" of copper in medicine and treatment. Biometals 2014, 27, 611-621. [CrossRef]

20. De Luca, A.; Barile, A.; Arciello, M.; Rossi, L. Copper homeostasis as target of both consolidated and innovative strategies of anti-tumor therapy. J. Trace Elem. Med. Biol. 2019, 55, 204-213. [CrossRef]

21. Quist, D.A.; Diaz, D.E.; Liu, J.J.; Karlin, K.D. Activation of dioxygen by copper metalloproteins and insights from model complexes. J. Biol. Inorg. Chem. 2017, 22, 253-288. [CrossRef] [PubMed]

22. Wehbe, M.; Leung, Y.; Abrams, M.J.; Orvig, C.; Bally, M.B. A Perspective-Can copper complexes be developed as a novel class of therapeutics? Dalton Trans. 2017, 46, 10758-10773. [CrossRef] [PubMed]

23. Galindo-Murillo, R.; Garcia-Ramos, J.C.; Ruiz-Azuara, L.; Cheatham, T.E., III; Cortes-Guzman, F. Intercalation processes of copper complexes in DNA. Nucleic Acids Res. 2015, 43, 5364-5376. [CrossRef] [PubMed]

24. Ingle, A.P.; Paralikar, P.; Shende, S.; Gupta, I.; Biswas, J.K.; da Silva Martins, L.H.; Rai, M. Chapter 4 Copper in medicine: Perspectives and toxicity. In Biomedical Applications of Metals; Rai, M., Ingle, A.P., Medici, S., Eds.; Springer International Publishing: Berlin/Heidelberg, Germany, 2018; pp. 95-112. [CrossRef]

25. Gaetke, L.M.; Chow-Johnson, H.S.; Chow, C.K. Copper: Toxicological relevance and mechanisms. Arch. Toxicol. 2014, 88, 1929-1938. [CrossRef]

26. Osredkar, J.; Sustar, N. Copper and zinc, biological role and significance of copper/zinc imbalance. J. Clinic. Toxicol. 2011, S3. [CrossRef]

27. Oon, S.; Yap, C.-H.; Ihle, B.U. Acute copper toxicity following copper glycinate injection. Intern. Med. J. 2006, 36, 741-743. [CrossRef]

28. Shabbir, Z.; Sardar, A.; Shabbir, A.; Abbas, G.; Shamshad, S.; Khalid, S.; Natasha; Murtaza, G.; Dumat, C.; Shahid, M. Copper uptake, essentiality, toxicity, detoxification and risk assessment in soil-plant environment. Chemosphere 2020, 259, 127436. [CrossRef]

29. Bonaccorso, C.; Marzo, T.; La Mendola, D. Biological Applications of Thiocarbohydrazones and Their Metal Complexes: A Perspective Review. Pharmaceuticals 2020, 12, 476. [CrossRef]

30. Santini, C.; Pellei, M.; Gandin, V.; Porchia, M.; Tisato, F.; Marzano, C. Advances in copper complexes as anticancer agents. Chem. Rev. 2014, 114, 815-862. [CrossRef]

31. Denoyer, D.; Clatworthy, S.A.S.; Cater, M.A. Copper Complexes in Cancer Therapy. Met. Ions Life Sci. 2018, 18, 469-506. [CrossRef] 
32. Ceramella, J.; Mariconda, A.; Iacopetta, D.; Saturnino, C.; Barbarossa, A.; Caruso, A.; Rosano, C.; Sinicropi, M.S.; Longo, P. From coins to cancer therapy: Gold, silver and copper complexes targeting human topoisomerases. Bioorg. Med. Chem. Lett. 2020, 30, 126905. [CrossRef] [PubMed]

33. Shagufta, A.I. Transition metal complexes as proteasome inhibitors for cancer treatment. Inorg. Chim. Acta 2020, 506, 119521. [CrossRef]

34. Duncan, C.; White, A.R. Copper complexes as therapeutic agents. Metallomics 2012, 4, 127-138. [CrossRef] [PubMed]

35. Szymański, P.; Frączek, T.; Markowicz, M.; Mikiciuk-Olasik, E. Development of copper based drugs, radiopharmaceuticals and medical materials. Biometals 2012, 25, 1089-1112. [CrossRef] [PubMed]

36. Rostas, A.M.; Badea, M.; Ruţă, L.L.; Farcaşanu, I.C.; Maxim, C.; Chifiriuc, M.C.; Popa, M.; Luca, M.; Čelan Korošin, N.; Cerc Korošec, R.; et al. Copper(II) complexes with mixed heterocycle ligands as promising antibacterial and antitumor species. Molecules 2020, 25, 3777. [CrossRef]

37. Medici, S.; Peana, M.; Nurchi, V.M.; Lachowicz, J.I.; Crisponi, G.; Zoroddu, M.A. Noble metals in medicine: Latest advances. Coord. Chem. Rev. 2015, 284, 329-350. [CrossRef]

38. Chylewska, A.; Biedulska, M.; Sumczyński, P.; Makowski, M. Metallopharmaceuticals in therapy-A new horizon for scientific research. Curr. Med. Chem. 2017, 25, 1729-1791. [CrossRef]

39. Shobha Devi, C.; Thulasiram, B.; Aerva, R.R.; Nagababu, P. Recent Advances in Copper Intercalators as Anticancer Agents. J. Fluoresc. 2018, 28, 1195-1205. [CrossRef]

40. Erxleben, A. Interactions of copper complexes with nucleic acids, Interactions of copper complexes with nucleic acids. Coord. Chem. Rev. 2018, 360, 92-121. [CrossRef]

41. Psomas, G. Copper(II) and zinc(II) coordination compounds of non-steroidal anti-inflammatory drugs: Structural features and antioxidant activity. Coord. Chem. Rev. 2020, 412, 213259. [CrossRef]

42. Maeda, H. Polymer therapeutics and the EPR effect. J. Drug Target. 2017, 25, 781-785. [CrossRef] [PubMed]

43. Callari, M.; Aldrich-Wright, J.R.; de Souza, P.L.; Stenzel, M.H. Polymers with platinum drugs and other macromolecular metal complexes for cancer treatment. Progress Polym. Sci. 2014, 39, 1614-1643. [CrossRef]

44. Poursharifi, M.; Wlodarczyk, M.T.; Mieszawska, A.J. Nano-Based Systems and Biomacromolecules as Carriers for Metallodrugs in Anticancer Therapy. Inorganics 2019, 7, 2. [CrossRef]

45. Nave, M.; Castro, R.E.; Rodrigues, C.M.P.; Casini, A.; Soveral, G.; Gaspar, M.M. Nanoformulations of a potent copper-based aquaporin inhibitor with cytotoxic effect against cancer cells. Nanomedicine 2016, 11, 1817-1830. [CrossRef]

46. Pinho, J.O.; Amaral, J.D.; Castro, R.E.; Rodrigues, C.M.P.; Casini, A.; Soveral, G.; Gaspar, M.M. Copper complex nanoformulations featuring highly promising therapeutic potential in murine melanoma models. Nanomedicine 2019, 14, 835-850. [CrossRef]

47. da Silva, P.B.; de Souza, P.C.; Fioramonti Calixto, G.M.; de O'Lopes, E.; Frem, R.C.G.; Netto, A.V.G.; Mauro, A.E.; Pavan, F.R.; Chorilli, M. In Vitro Activity of Copper(II) Complexes, Loaded or Unloaded into a Nanostructured Lipid System, against Mycobacterium tuberculosis. Int. J. Mol. Sci. 2016, 17, 745. [CrossRef]

48. Silva, P.B.; Bonifacio, B.V.; Frem, R.C.G.; Godoy Netto, A.V.; Mauro, A.E.; Da Costa Ferreira, A.M.; Lopes, E.O.; Raddi, M.S.G.; Bauab, T.M.; Pavan, F.R.; et al. A nanostructured lipid system as a strategy to improve the in vitro antibacterial activity of copper(II) complexes. Molecules 2015, 20, 22534-22545. [CrossRef]

49. Wehbe, M.; Anantha, M.; Backstrom, I.; Leung, A.; Chen, K.; Malhotra, A.; Edwards, K.; Bally, M.B. Nanoscale Reaction Vessels Designed for Synthesis of Copper-Drug Complexes Suitable for Preclinical Development. PLoS ONE 2016, 11, e0153416. [CrossRef]

50. Wang, Y.; Zeng, S.; Lin, T.-M.; Krugner-Higby, L.; Lyman, D.; Steffen, D.; Xiong, M.P. Evaluating the anticancer properties of liposomal copper in a nude xenograft mouse model of human prostate cancer: Formulation, in vitro, in vivo, histology and tissue distribution studies. Pharm. Res. 2014, 31, 3106-3119. [CrossRef]

51. Gaál, A.; Garay, T.M.; Horváth, I.; Máthé, D.; Szöllosi, D.; Veres, D.S.; Mbuotidem, J.; Kovács, T.; Tóvári, J.; Bergmann, R.; et al. Development and In Vivo Application of a Water-Soluble Anticancer Copper Ionophore System Using a Temperature-Sensitive Liposome Formulation. Pharmaceutics 2020, 12, 466. [CrossRef]

52. Chen, K.T.J.; Anantha, M.; Leung, A.W.Y.; Kulkarni, J.A.; Militao, G.G.C.; Wehbe, M.; Sutherland, B.; Cullis, P.R.; Bally, M.B. Characterization of a liposomal copper(II)-quercetin formulation suitable for parenteral use. Drug Deliv. Transl. Res. 2020, 10, 202-215. [CrossRef] [PubMed] 
53. Kaur, B.; Kaur, G.; Chaudhary, G.R.; Sharma, V.K.; Srinivasan, H.; Mitra, S.; Sharma, A.; Gawali, S.L.; Hassan, P.A. An investigation of morphological, microscopic dynamics, fluidity, and physicochemical variations in Cu-decorated metallosomes with cholesterol. J. Mol. Liq. 2020, 318, 114034. [CrossRef]

54. Vorauer-Uhl, K.; Fürnschlief, E.; Wagner, A.; Ferko, B.; Katinger, H. Topically applied liposome encapsulated superoxide dismutase reduces postburn wound size and edema formation. Eur. J. Pharm. Sci. 2001, 14, 63-67. [CrossRef]

55. Corvo, L.M.; Jorge, J.C.; Van't Hof, R.; Cruz, M.E.; Crommelin, D.J.; Storm, G. Superoxide dismutase entrapped in long-circulating liposomes: Formulation design and therapeutic activity in rat adjuvant arthritis. Biochim. Biophys. Acta 2002, 1564, 227-236. [CrossRef]

56. Corvo, L.M.; Marinho, H.S.; Marcelino, P.; Lopes, R.M.; Vale, C.A.; Marques, C.R.; Martins, L.C.D.; Laverman, P.; Storm, G.; Martins, M.B.A.F. Superoxide dismutase enzymosomes: Carrier capacity optimization, in vivo behaviour and therapeutic activity. Pharm. Res. 2015, 32, 91-102. [CrossRef]

57. Galović Rengel, R.; Barisić, K.; Pavelić, Z.; Zanić Grubisić, T.; Cepelak, I.; Filipović Grcić, J. High efficiency entrapment of superoxide dismutase into mucoadhesive chitosan-coated liposomes. Eur. J. Pharm. Sci. 2002, 15, 441-448. [CrossRef]

58. Ishihara, T.; Nara, S.; Mizushima, T. Interactions of lecithinized superoxide dismutase with serum proteins and cells. J. Pharm. Sci. 2014, 103, 1987-1994. [CrossRef]

59. Veronese, F.M.; Caliceti, P.; Schiavon, O.; Sergi, M. Polyethylene glycol-superoxide dismutase, a conjugate in search of exploitation. Adv. Drug Deliv. Rev. 2002, 54, 587-606. [CrossRef]

60. Reddy, M.K.; Wu, L.; Kou, W.; Ghorpade, A.; Labhasetwar, V. Superoxide dismutase loaded PLGA nanoparticles protect cultured human neurons under oxidative stress. Appl. Biochem. Biotechnol. 2008, 151, 565-577. [CrossRef]

61. Reddy, M.K.; Labhasetwar, V. Nanoparticle-mediated delivery of superoxide dismutase to the brain: An effective strategy to reduce ischemia-reperfusion injury. FASEB J. 2009, 23, 1384-1395. [CrossRef]

62. Manickam, D.S.; Brynskikh, A.M.; Kopanic, J.L.; Sorgen, P.L.; Klyachko, N.L.; Batrakova, E.V.; Bronich, T.K.; Kabanov, A.V. Well-defined cross-linked antioxidant nanozymes for treatment of ischemic brain injury. J. Control. Release 2012, 162, 636-645. [CrossRef] [PubMed]

63. Rosenbaugh, E.G.; Roat, J.W.; Gao, L.; Yang, R.-F.; Manickam, D.S.; Yin, J.X.; Schultz, H.D.; Bronich, T.K.; Batrakova, E.V.; Kabanov, A.V.; et al. The attenuation of central angiotensin II-dependent pressor response and intra-neuronal signaling by intracarotid injection of nanoformulated copper/zinc superoxide dismutase. Biomaterials 2010, 31, 5218-5226. [CrossRef] [PubMed]

64. Giovagnoli, S.; Luca, G.; Casaburi, I.; Blasi, P.; Macchiarulo, G.; Ricci, M.; Calvitti, M.; Basta, G.; Calafiore, R.; Rossi, C. Long-term delivery of superoxide dismutase and catalase entrapped in poly(lactide-co-glycolide) microspheres: In vitro effects on isolated neonatal porcine pancreatic cell clusters. J. Control. Release 2005, 107, 65-77. [CrossRef] [PubMed]

65. Giovagnoli, S.; Blasi, P.; Ricci, M.; Rossi, C. Biodegradable microspheres as carriers for native superoxide dismutase and catalase delivery. AAPS PharmSciTech 2004, 5, e51. [CrossRef]

66. Kartha, S.; Yan, L.; Weisshaar, C.L.; Ita, M.E.; Shuvaev, V.V.; Muzykantov, V.R.; Tsourkas, A.; Winkelstein, B.A.; Cheng, Z. Superoxide Dismutase-Loaded Porous Polymersomes as Highly Efficient Antioxidants for Treating Neuropathic Pain. Adv. Healthcare Mater. 2017, 6, 1700500. [CrossRef]

67. Beckman, J.S.; Minor, R.L.; White, C.W.; Repine, J.E.; Rosen, G.M.; Freeman, B.A. Superoxide dismutase and catalase conjugated to polyethylene glycol increases endothelial enzyme activity and oxidant resistance. J. Biol. Chem. 1988, 263, 6884-6892.

68. Jiang, Y.; Brynskikh, A.M.; Manickam, D.S.; Kabanov, A.V. SOD1 nanozyme salvages ischemic brain by locally protecting cerebral vasculature. J. Control. Release 2015, 213, 36-44. [CrossRef]

69. Jiang, Y.; Arounleut, P.; Rheiner, S.; Bae, Y.; Kabanov, A.V.; Milligan, C.; Manickam, D.S. SOD1 nanozyme with reduced toxicity and MPS accumulation. J. Control. Release 2016, 231, 38-49. [CrossRef]

70. Chang, R.; Hsu, C.-F.; Tsai, W.-B. Fabrication of Chlorophyll-Incorporated Nanogels for Potential Applications in Photothermal Cancer Therapy. ACS Omega 2018, 3, 16057-16062. [CrossRef]

71. Chang, R.; Tsai, W.-B. Fabrication of Photothermo-Responsive Drug-Loaded Nanogel for Synergetic Cancer Therapy. Polymers 2018, 10, 1098. [CrossRef] 
72. Wonoputri, V.; Gunawan, C.; Liu, S.; Barraud, N.; Yee, L.H.; Lim, M.; Amal, R. Copper Complex in Poly(vinyl chloride) as a Nitric Oxide-Generating Catalyst for the Control of Nitrifying Bacterial Biofilms. ACS Appl. Mater. Interfaces 2015, 7, 22148-22156. [CrossRef] [PubMed]

73. Wonoputri, V.; Gunawan, C.; Liu, S.; Barraud, N.; Yee, L.H.; Lim, M.; Amal, R. Iron Complex Facilitated Copper Redox Cycling for Nitric Oxide Generation as Nontoxic Nitrifying Biofilm Inhibitor. ACS Appl. Mater. Interfaces 2016, 8, 30502-30510. [CrossRef]

74. Xiao, J.; Chen, S.; Yi, J.; Zhang, H.; Ameer, G.A. A Cooperative Copper Metal-Organic Framework-Hydrogel System Improves Wound Healing in Diabetes. Adv. Funct. Mater. 2017, 27, 1604872. [CrossRef]

75. Zhang, Y.; Zhao, Q.; Li, W.; Liu, J.; Chen, J.; Fan, Y.; Weng, Y. Substrate Independent Liquid Phase Epitaxy of HKUST-1 as Anticoagulant and Antimicrobial Coating. Adv. Mater. Interfaces 2020, 7, 1902011. [CrossRef]

76. Liu, S.; Wang, L.; Li, S.; Meng, X.; Sun, B.; Zhang, X.; Zhang, L.; Liu, Y.; Lin, M.; Zhang, H.; et al. Multidrug resistant tumors-aimed theranostics on the basis of strong electrostatic attraction between resistant cells and nanomaterials. Biomater. Sci. 2019, 7, 4990-5001. [CrossRef] [PubMed]

77. Peng, X.; Pan, Q.; Zhang, B.; Wan, S.; Li, S.; Luo, K.; Pu, Y.; He, B. Highly Stable, Coordinated Polymeric Nanoparticles Loading Copper(II) Diethyldithiocarbamate for Combinational Chemo/Chemodynamic Therapy of Cancer. Biomacromolecules 2019, 20, 2372-2383. [CrossRef] [PubMed]

78. Zhong, Y.; Sun, R.; Geng, Y.; Zhou, Q.; Piao, Y.; Xie, T.; Zhou, R.; Shen, Y. N-Oxide Polymer-Cupric Ion Nanogels Potentiate Disulfiram for Cancer Therapy. Biomater. Sci. 2020, 8, 1726-1733. [CrossRef] [PubMed]

79. Eskandari, A.; Boodram, J.N.; Cressey, P.B.; Lu, C.; Bruno, P.M.; Hemann, M.T.; Suntharalingam, K. The Breast Cancer Stem Cell Potency of Copper(II) Complexes Bearing Nonsteroidal Anti-Inflammatory Drugs and Their Encapsulation Using Polymeric Nanoparticles. Dalton Trans. 2016, 45, 17867-17873. [CrossRef]

80. Godbey, W.T.; Wu, K.K.; Mikos, A.G. Poly(ethylenimine) and its role in gene delivery. J. Control. Release 1999, 60, 149-160. [CrossRef]

81. Kumar, R.S.; Arunachalam, S. DNA binding and antimicrobial studies of some polyethyleneimine-copper(II) complex samples containing 1,10-phenanthroline and L-threonine as co-ligands. Polyhedron 2007, 26, 3255-3262. [CrossRef]

82. Kumar, R.S.; Arunachalam, S. DNA binding and antimicrobial studies of polymer-copper(II) complexes containing 1,10-phenanthroline and L-phenylalanine ligands. Eur. J. Med. Chem. 2009, 44, 1878-1883. [CrossRef] [PubMed]

83. Kumar, R.S.; Arunachalam, S.; Periasamy, V.S.; Preethy, C.P.; Riyasdeen, A. DNA binding and biological studies of some novel water-soluble polymer-copper(II)-phenanthroline complexes. Eur. J. Med. Chem. 2008, 43, 2082-2091. [CrossRef] [PubMed]

84. Kumar, R.S.; Sasikala, K.; Arunachalam, S. DNA interaction of some polymer-copper(II) complexes containing 2,2'-bipyridyl ligand and their antimicrobial activities. J. Inorg. Biochem. 2008, 102, $234-241$. [CrossRef] [PubMed]

85. Kumar, R.S.; Periasamy, V.S.; Paul, C.P.; Riyasdeen, A.; Arunachalam, S.; Akbarsha, M.A. Cytotoxic effect of a polymer-copper(II) complex containing 2,2'-bipyridyl ligand on human lung cancer cells. Med. Chem. Res. 2011, 20, 726-731. [CrossRef]

86. Hausman, R.; Gullinkala, T.; Escobar, I.C. Development of Low-Biofouling Polypropylene Feedspacers for Reverse Osmosis. J. Appl. Polym. Sci. 2009, 114, 3068-3073. [CrossRef]

87. Saleh, S.; Sweileh, B.; Taha, S.O.; Mahmoud, R.; Taha, M.O. Preparation of Polyester-Based Metal-Cross Linked Polymeric Composites as Novel Materials Resistant to Bacterial Adhesion and Biofilm Formation. Molecules 2011, 16, 933-950. [CrossRef]

88. Talukdar, M.I.A.; Ahamad, I.; Iqbal, S.; Malik, M.A.; Dar, O.A.; Akram, M.d.K.; Fatma, T.; Hashmi, A.A. Fabrication of metal incorporated polymer composite: An excellent antibacterial agent. J. Mol. Struct. 2021, 1225, 129091. [CrossRef]

89. Galliani, M.; Signore, G. Poly(Lactide-Co-Glycolide) Nanoparticles Co-Loaded with Chlorophyllin and Quantum Dots as Photodynamic Therapy Agents. ChemPlusChem 2019, 84, 1653-1658. [CrossRef]

90. Li, S.; Cui, S.; Yin, D.; Zhu, Q.; Ma, Y.; Qian, Z.; Gu, Y. Dual antibacterial activities of a chitosan-modified upconversion photodynamic therapy system against drug-resistant bacteria in deep tissue. Nanoscale 2017, 9, 3912-3924. [CrossRef]

91. Arimoto-Kobayashi, S.; Harada, N.; Tokunaga, R.; Odo, J.-I.; Hayatsu, H. Adsorption of mutagens to chlorophyllin-chitosan, an insoluble form of chlorophyllin. Mutat. Res. 1997, 381, 243-249. [CrossRef] 
92. Celik, O.; Akbuğa, J. Preparation of superoxide dismutase loaded chitosan microspheres: Characterization and release studies. Eur. J. Pharm. Biopharm. 2007, 66, 42-47. [CrossRef] [PubMed]

93. Wang, R.-M.; He, N.-P.; He, Y.-F.; Xie, Y.-T.; Wang, Y.-P.; Tsuchida, E. The preparation of nano-scope chitosanoligomer copper complexes and their interaction with DNA. Polym. Adv. Technol. 2005, 16, 638-641. [CrossRef]

94. Wang, R.-M.; He, N.-P.; Song, P.-F.; He, Y.-F.; Ding, L.; Lei, Z.-Q. Preparation of nano-chitosan Schiff-base copper complexes and their anticancer activity. Polym. Adv. Technol. 2009, 20, 959-964. [CrossRef]

95. Malekshaha, R.E.; Shakerib, F.; Khaleghianb, A.; Salehi, M. Developing a biopolymeric chitosan supported Schiff-base and $\mathrm{Cu}(\mathrm{II}), \mathrm{Ni}(\mathrm{II})$ and $\mathrm{Zn}(\mathrm{II})$ complexes and biological evaluation as Pro-drug. Int. J. Biol. Macromol. 2020, 152, 846-861. [CrossRef] [PubMed]

96. Miranda-Calderón, J.E.; Macías-Rosales, L.; Gracia-Mora, I.; Ruiz-Azuara, L.; Faustino-Vega, A.; Gracia-Mora, J.; Bernad-Bernad, M.J. Effect of casiopein III-ia loaded into chitosan nanoparticles on tumor growth inhibition. J. Drug Deliv. Sci. Technol. 2018, 48, 1-8. [CrossRef]

97. Gritsch, L.; Liverani, L.; Lovell, C.; Boccaccini, A.R. Polycaprolactone Electrospun Fiber Mats Prepared Using Benign Solvents: Blending with Copper(II)-Chitosan Increases the Secretion of Vascular Endothelial Growth Factor in a Bone Marrow Stromal Cell Line. Macromol. Biosci. 2020, 20, 1900355. [CrossRef]

98. Ren, X.; Yang, C.; Zhang, L.; Li, S.; Shi, S.; Wang, R.; Zhang, X.; Yue, T.; Sun, J.; Wang, J. Copper metal-organic frameworks loaded on chitosan film for the efficient inhibition of bacteria and local infection therapy. Nanoscale 2019, 11, 11830-11838. [CrossRef]

99. Gritsch, L.; Lovell, C.; Goldmann, W.H.; Boccaccini, A.R. Fabrication and characterization of copper(II)-chitosan complexes as antibiotic-free antibacterial biomaterial. Carbohydr. Polym. 2018, 179, 370-378. [CrossRef]

100. Ma, Y.; Yua, H.; Liua, W.; Qin, Y.; Xinga, R.; Li, P. Integrated proteomics and metabolomics analysis reveals the antifungal mechanism of the C-coordinated O-carboxymethyl chitosan $\mathrm{Cu}$ (II) complex. Int. J. Biol. Macromol. 2020, 155, 1491-1509. [CrossRef]

101. Barbucci, R.; Magnani, A.; Lamponi, S.; Mitola, S.; Ziche, M.; Morbidelli, L.; Bussolino, F. Cu(II) and Zn(II) complexes with hyaluronic acid and its sulphated derivative: Effect on the motility of vascular endothelial cells. J. Inorg. Biochem. 2000, 81, 229-237. [CrossRef]

102. Barbucci, R.; Leone, G.; Magnani, A.; Montanaro, L.; Arciola, C.R.; Peluso, G.; Petillo, O. Cu ${ }^{2+}-$ and $\mathrm{Ag}^{+}$-complexes with a hyaluronane-based hydrogel. J. Mater. Chem. 2002, 12, 3084-3092. [CrossRef]

103. Hu, C.; Cai, L.; Liu, S.; Liu, Y.; Zhou, Y.; Pang, M. Copper-doped Nanoscale Covalent Organic Polymer for Augmented Photo-/Chemodynamic Synergistic Therapy and Immunotherapy. Bioconjug. Chem. 2020, 31, 1661-1670. [CrossRef] [PubMed]

104. Tabata, Y.; Matsui, Y.; Ikada, Y. Growth factor release from amylopectin hydrogel based on copper coordination. J. Control. Release 1998, 56, 135-148. [CrossRef]

105. Tabata, Y.; Noda, Y.; Matsui, Y.; Ikada, Y. Targeting of tumor necrosis factor to tumor by use of dextran and metal coordination. J. Control. Release 1999, 59, 187-196. [CrossRef]

106. Gombotz, W.R.; Wee, S.F. Protein release from alginate matrices. Adv. Drug. Deliv. Rev. 1998, 31, 267-285. [CrossRef]

107. Tawfik, S.M.; Hefni, H.H. Synthesis and antimicrobial activity of polysaccharide alginate derived cationic surfactant-metal(II) complexes. Int. J. Biol. Macromol. 2016, 82, 562-572. [CrossRef]

108. Suzuki, R.; Inoue, Y.; Murata, I.; Nomura, H.; Isshiki, Y.; Hashimoto, M.; Kudo, Y.; Kitagishi, H.; Kondo, S.; Kanamoto, I. Preparation, characterization, and study of the antimicrobial activity of a Hinokitiol-copper(II)/gamma-cyclodextrin ternary complex. J. Mol. Struct. 2019, 1194, e27. [CrossRef]

109. Xia, N.; Wan, W.; Zhu, S.; Liu, Q. Preparation of crystalline nanocellulose/hydroxypropyl $\beta$ cyclodextrin/carboxymethyl cellulose polyelectrolyte complexes and their controlled release of neohesperidin-copper (II) in vitro. Int. J. Biol. Macromol. 2020, 163, 1518-1528. [CrossRef]

110. Gómez-Machuca, H.; Quiroga-Campano, C.; Zapata-Torres, G.; Jullian, C. Influence of DM $\beta C D$ on the Interaction of Copper(II) Complex of 6-Hydroxychromone-3-carbaldehyde-3-hydroxybenzoylhydrazine with ctDNA, ACS Omega 2020, 5, 6928-6936. [CrossRef]

111. Demirdogen, R.E.; Kilic, D.; Emen, F.M.; Așkar, Ș.; Karaçolak, A.I.; Yesilkaynak, T.; Ihsan, A. Novel antibacterial cellulose acetate fibers modified with 2-fluoropyridine complexes. J. Mol. Struct. 2020, 1204, 127537. [CrossRef] 
112. Xua, Y.; Shia, Y.; Leia, F.; Dai, L. A novel and green cellulose-based Schiff base-Cu (II) complex and its excellent antibacterial activity. Carbohydr. Polym. 2020, 230, 115671. [CrossRef] [PubMed]

113. Norman, M.; Bartczak, P.; Zdarta, J.; Tomala, W.; Żurańska, B.; Dobrowolska, A.; Piasecki, A.; Czaczyk, K.; Ehrlich, H.; Jesionowski, T. Sodium Copper Chlorophyllin Immobilization onto Hippospongia communis Marine Demosponge Skeleton and Its Antibacterial Activity. Int. J. Mol. Sci. 2016, 17, 1564. [CrossRef] [PubMed]

114. Glassman, P.M.; Walsh, L.R.; Villa, C.H.; Marcos-Contreras, O.A.; Hood, E.D.; Muzykantov, V.R.; Greineder, C.F. Molecularly Engineered Nanobodies for Tunable Pharmacokinetics and Drug Delivery. Bioconjug. Chem. 2020, 31, 1144-1155. [CrossRef] [PubMed]

115. Shuvaev, V.V.; Khoshnejad, M.; Pulsipher, K.W.; Kiseleva, R.Y.; Arguiri, E.; Cheung-Lau, J.C.; LeFort, K.M.; Christofidou-Solomidou, M.; Stan, R.V.; Dmochowski, I.J.; et al. Spatially controlled assembly of affinity ligand and enzyme cargo enables targeting ferritin nanocarriers to caveolae. Biomaterials 2018, 185, 348-359. [CrossRef] [PubMed]

116. Shuvaev, V.V.; Kiseleva, R.Y.; Arguiri, E.; Villa, C.H.; Muro, S.; Christofidou-Solomidou, M.; Stan, R.V.; Muzykantov, V.R. Targeting superoxide dismutase to endothelial caveolae profoundly alleviates inflammation caused by endotoxin. J. Control. Release 2018, 272, 1-8. [CrossRef]

117. Shuvaev, V.V.; Muro, S.; Arguiri, E.; Khoshnejad, M.; Tliba, S.; Christofidou-Solomidou, M.; Muzykantov, V.R. Size and targeting to PECAM vs ICAM control endothelial delivery, internalization and protective effect of multimolecular SOD conjugates. J. Control. Release 2016, 234, 115-123. [CrossRef]

118. Hu, D.; Xu, H.; Xiao, B.; Li, D.; Zhou, Z.; Liu, X.; Tang, J.; Shen, Y. Albumin stabilized metal-organic nanoparticles for effective delivery of metal complex anticancer drugs. ACS Appl. Mater. Interfaces 2018, 10, 34974-34982. [CrossRef]

119. Llamazares, C.; Sanz del Olmo, N.; Ortega, P.; Gómez, R.; Soliveri, J.; Javier de la Mata, F.; García-Gallego, S.; Copa-Patiño, J.L. Antibacterial Effect of Carbosilane Metallodendrimers in Planktonic Cells of Gram-Positive and Gram-Negative Bacteria and Staphylococcus aureus Biofilm. Biomolecules 2019, 9, 405. [CrossRef]

120. Bosch, P.; Staneva, D.; Vasileva-Tonkova, E.; Grozdanov, P.; Nikolova, I.; Kukeva, R.; Stoyanova, R.; Grabchev, I. New Poly(Propylene Imine) Dendrimer Modified with Acridine and Its Cu(II) Complex: Synthesis, Characterization and Antimicrobial Activity. Materials 2019, 12, 3020. [CrossRef]

121. Grabchev, I.; Vasileva-Tonkova, E.; Staneva, D.; Bosch, P.; Kukeva, R.; Stoyanova, R. Synthesis, spectral characterization and in vitro antimicrobial activity in liquid medium and applied on cotton fabric of a new PAMAM metallodendrimer. Int. J. Polym. Anal. Char. 2018, 23, 45-57. [CrossRef]

122. Grabcheva, I.; Vasileva-Tonkovab, E.; Stanevac, D.; Boschd, P.; Kukevae, R.; Stoyanova, R. Impact of the $\mathrm{Cu}(\mathrm{II})$ and $\mathrm{Zn}(\mathrm{II})$ ions on the functional properties of new PAMAM metallodendrimers. New J. Chem. 2018, 42, 7853-7862. [CrossRef]

123. Caminade, A.-M.; Majoral, J.-P. Phosphorus dendrimers functionalised with nitrogen ligands, for catalysis and biology. Dalton Trans. 2019, 48, 7483-7493. [CrossRef] [PubMed]

124. El Brahmi, N.; El Kazzouli, S.; Mignani, S.M.; Essassi, E.M.; Aubert, G.; Laurent, R.; Caminade, A.-M.; Bousmina, M.M.; Cresteil, T.; Majoral, J.-P. Original Multivalent Copper(II)-Conjugated Phosphorus Dendrimers and Corresponding Mononuclear Copper(II) Complexes with Antitumoral Activities. Mol. Pharm. 2013, 10, 1459-1464. [CrossRef] [PubMed]

125. Mignani, S.; El Brahmi, N.; Eloy, L.; Poupon, J.; Nicolas, V.; Steinmetz, A.; El Kazzouli, S.; Bousmina, M.M.; Blanchard-Desce, M.; Caminade, A.M.; et al. Anticancer copper(II) phosphorus dendrimers are potent proapoptotic Bax activators. Eur. J. Med. Chem. 2017, 132, 142-156. [CrossRef] [PubMed]

126. Ottaviani, M.F.; El Brahmi, N.; Cangiotti, M.; Coppola, C.; Buccella, F.; Cresteil, T.; Mignani, S.; Caminade, A.M.; Costes, J.P.; Majoral, J.P. Comparative EPR studies of $\mathrm{Cu}(\mathrm{II})$-conjugated phosphorous-dendrimers in the absence and presence of normal and cancer cells. RSC Adv. 2014, 4, 36573-36583. [CrossRef]

127. Fan, Y.; Lin, L.; Yin, F.; Zhu, Y.; Shen, M.; Wang, H.; Du, L.; Mignani, S.; Majorale, J.-P.; Shi, X. Phosphorus dendrimer-based copper(II) complexes enable ultrasound-enhanced tumor theranostics. Nano Today 2020, 33, 100899. [CrossRef]

128. Mignani, S.M.; El Brahmi, N.; El Kazzouli, S.; Laurent, R.; Ladeira, S.; Caminade, A.-M.; Pedziwiatr-Werbicka, E.; Szewczyk, E.M.; Bryszewska, M.; Bousmina, M.M.; et al. Original Multivalent Gold(III) and Dual Gold(III)-Copper(II) Conjugated Phosphorus Dendrimers as Potent Antitumoral and Antimicrobial Agents. Mol. Pharm. 2017, 14, 4087-4097. [CrossRef] 
129. Canonico, B.; Carloni, R.; Sanz Del Olmo, N.; Papa, S.; Nasoni, M.G.; Fattori, A.; Cangiotti, M.; De La Mata, F.J.; Ottaviani, M.F.; García-Gallego, S. Fine-Tuning the Interaction and Therapeutic Effect of Cu(II) Carbosilane Metallodendrimers in Cancer Cells: An in Vitro Electron Paramagnetic Resonance Study. Mol. Pharm. 2020, 17, 2691-2702. [CrossRef]

130. Sanz del Olmo, N.; Carloni, R.; Bajo, A.M.; Ortega, P.; Fattori, A.; Gómez, R.; Ottaviani, M.F.; García-Gallego, S.; Cangiotti, M.; Javier de la Mata, F. Insight into the antitumor activity of carbosilane $\mathrm{Cu}(\mathrm{II})$-metallodendrimers through their interaction with biological membrane models. Nanoscale 2019, 11, 13330-13342. [CrossRef]

131. Sanz del Olmo, N.; Holota, M.; Michlewska, S.; Gómez, R.; Ortega, P.; Ionov, M.; Javier de la Mata, F.; Bryszewska, M. Copper (II) Metallodendrimers Combined with Pro-Apoptotic siRNAs as a Promising Strategy Against Breast Cancer Cells. Pharmaceutics 2020, 12, 727. [CrossRef]

132. Holota, M.; Magiera, J.; Michlewska, S.; Kubczak, M.; Sanz del Olmo, N.; García-Gallego, S.; Ortega, P.; Javier de la Mata, F.; Ionov, M.; Bryszewska, M. In Vitro Anticancer Properties of Copper Metallodendrimers. Biomolecules 2019, 9, 155. [CrossRef] [PubMed]

133. Fan, Y.; Zhang, Y.; Zhaoa, Q.; Xie, Y.; Luo, R.; Yang, P.; Weng, Y. Immobilization of nano Cu-MOFs with polydopamine coating for adaptable gasotransmitter generation and copper ion delivery on cardiovascular stents. Biomaterials 2019, 204, 36-45. [CrossRef]

134. Oliveira, G.R.; do Amaral, L.J.; Giovanela, M.; da Silva Crespo, J.; Fetter, G.; Rivera, J.A.; Sampieri, A.; Bosch, P. Bactericidal performance of chlorophyllin-copper hydrotalcite compounds. Water Air Soil. Pollut. 2015, 226, 1-12. [CrossRef]

135. Azimi, S.; Behin, J.; Abiri, R.; Rajabi, L.; Derakhshan, A.A.; Karimnezhad, S.H. Synthesis, characterization and antibacterial activity of chlorophyllin functionalized graphene oxide nanostructures. Sci. Adv. Mater. 2014, 6, 771-781. [CrossRef]

136. Singh, S.; Dubey, V.K. Multiwalled Carbon Nanotube-Superoxide Dismutase Conjugate Towards Alleviating Induced Oxidative Stress. Int. J. Pept. Res. Ther. 2016, 22, 171-177. [CrossRef]

137. Binevski, P.V.; Balabushevich, N.G.; Uvarova, V.I.; Vikulina, A.S.; Volodkin, D. Bio-friendly encapsulation of superoxide dismutase into vaterite $\mathrm{CaCO}_{3}$ crystals. Enzyme activity, release mechanism, and perspectives for ophthalmology. Colloids Surf. B Biointerfaces 2019, 181, 437-449. [CrossRef] [PubMed]

138. López, T.; Ortiz, E.; Guevara, P.; Gómez, E.; Novaro, O. Physicochemical characterization of functionalized nanostructured-titania as a carrier of copper complexes for cancer treatment. Mater. Chem. Phys. 2014, 146, 37-49. [CrossRef]

139. Bernardos, A.; Piacenza, E.; Sancenón, F.; Hamidi, M.; Maleki, A.; Turner, R.J.; Martínez-Máñez, R. Mesoporous Silica-Based Materials with Bactericidal Properties. Small 2019, 15, 1900669. [CrossRef]

140. Kuthati, Y.; Kankala, R.K.; Busa, P.; Lin, S.-X.; Deng, J.-P.; Mou, C.-Y.; Lee, C.-H. Phototherapeutic spectrum expansion through synergistic effect of mesoporous silica trio-nanohybrids against antibiotic-resistant gram-negative bacterium. J. Photochem. Photobiol. B 2017, 169, 124-133. [CrossRef]

141. Tahmasbi, L.; Sedaghat, T.; Motamedi, H.; Kooti, M. Mesoporous silica nanoparticles supported copper(II) and nickel(II) Schiff base complexes: Synthesis, characterization, antibacterial activity and enzyme immobilization. J. Solid State Chem. 2018, 258, 517-525. [CrossRef]

142. Díaz-García, D.; Ardiles, P.; Prashar, S.; Rodríguez-Diéguez, A.; Páez, P.; Gómez-Ruiz, S. Preparation and Study of the Antibacterial Applications and Oxidative Stress Induction of Copper Maleamate-Functionalized Mesoporous Silica Nanoparticles. Pharmaceutics 2019, 11, 30. [CrossRef] [PubMed]

143. Díaz-García, D.; Ardiles, P.R.; Díaz-Sánchez, M.; Mena-Palomo, I.; del Hierro, I.; Prashar, S.; Rodríguez-Diéguez, A.; Páez, P.L.; Gómez-Ruiz, S. Copper-functionalized nanostructured silica-based systems: Study of the antimicrobial applications and ROS generation against gram positive and gram negative bacteria. J. Inorg. Biochem. 2020, 203, 110912. [CrossRef] [PubMed]

144. Patriarca, M.; Daier, V.; Camí, G.; Rivière, E.; Hureau, C.; Signorella, S. Preparation, characterization and activity of $\mathrm{CuZn}$ and $\mathrm{Cu} 2$ superoxide dismutase mimics encapsulated in mesoporous silica. J. Inorg. Biochem. 2020, 207, 111050. [CrossRef] [PubMed]

145. Sheena, T.S.; Dhivya, R.; Rajiu, V.; Jeganathan, K.; Palaniandavar, M.; Mathan, G.; Akbarsha, M.A. Folate-engineered mesoporous silica-encapsulated copper (II) complex [Cu (L)(dppz)]+: An active targeting cell-specific platform for breast cancer therapy. Inorg. Chim. Acta 2020, 510, 119783. [CrossRef] 
146. Sudareva, N.; Suvorova, O.; Saprykina, N.; Vilesov, A.; Bel'tyukov, P.; Petunov, S. Alginate-containing systems for oral delivery of superoxide dismutase. Comparison of various configurations and their properties. J. Microencapsul. 2016, 33, 487-496. [CrossRef] [PubMed]

147. Pramanik, A.K.; Palanimuthu, D.; Somasundaram, K.; Samuelson, A.G. Biotin Decorated Gold Nanoparticles for Targeted Delivery of a Smart-Linked Anticancer Active Copper Complex: In Vitro and In Vivo Studies. Bioconjug. Chem. 2016, 27, 2874-2885. [CrossRef] [PubMed]

148. Akhtar, M.A.; Ilyas, K.; Dlouhý, I.; Siska, F.; Boccaccini, A.R. Electrophoretic Deposition of Copper(II)-Chitosan Complexes for Antibacterial Coatings. Int. J. Mol. Sci. 2020, 21, 2637. [CrossRef]

149. Ahmadi, A.; Sedaghat, T.; Motamedi, H.; Azadi, R. Anchoring of Cu (II)-Schiff base complex on magnetic mesoporous silica nanoparticles: Catalytic efficacy in one-pot synthesis of 5-substituted-1H-tetrazoles, antibacterial activity evaluation and immobilization of $\alpha$-amylase. Appl. Organometal. Chem. 2020, e5572. [CrossRef]

Publisher's Note: MDPI stays neutral with regard to jurisdictional claims in published maps and institutional affiliations.

(C) 2020 by the authors. Licensee MDPI, Basel, Switzerland. This article is an open access article distributed under the terms and conditions of the Creative Commons Attribution (CC BY) license (http://creativecommons.org/licenses/by/4.0/). 